\title{
ATTENTION DISCRIMINATION: THEORY AND FIELD EXPERIMENTS
}

Vojtěch Bartoš Michal Bauer Julie Chytilová Filip Matějka
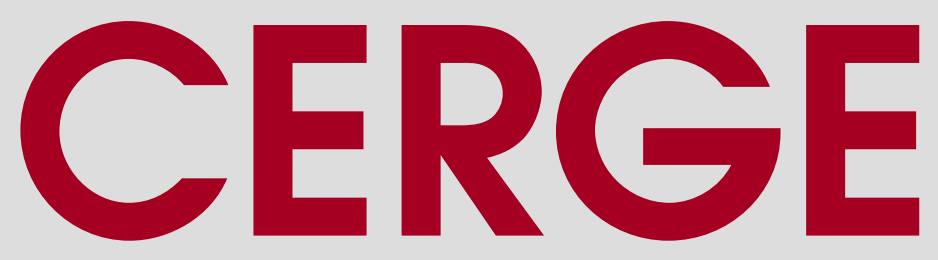

Cha res University

Centerfor Economic Research and Graduate Education

Academy of Sciences of the Czech Republic

Ec onomic Institute 


\title{
Working Paper Series 499 (ISSN 1211-3298)
}

\section{Attention Discrimination: Theory and Field Experiments}

\author{
Vojtěch Bartoš \\ Michal Bauer \\ Julie Chytilová \\ Filip Matějka
}

\section{CERGE-EI}

Prague, December 2013 
ISBN 978-80-7343-303-1 (Univerzita Karlova. Centrum pro ekonomický výzkum a doktorské studium)

ISBN 978-80-7344-296-5 (Akademie věd České republiky. Národohospodářský ústav) 


\title{
Attention Discrimination: Theory and Field Experiments*
}

\section{Vojtěch Bartoš $^{\dagger}$, Michal Bauer ${ }^{\dagger \#}$, Julie Chytilová ${ }^{\#}$, and Filip Matějka ${ }^{\dagger}$}

\author{
CERGE-EI in Prague ${ }^{\dagger}$
}

\author{
Charles University in Prague ${ }^{\#}$
}

\begin{abstract}
We link two important ideas: attention is scarce and a lack of information about an individual drives discrimination in selection decisions. We model how knowledge of ethnicity influences allocation of attention to available information about an applicant. When only a small share of applicants is accepted, negative stereotypes are predicted to lower attention, while the effect is opposite when most applicants are accepted. We test for such "attention discrimination" in two field experiments. We send emails responding to job offers and apartment-rental advertisements and monitor information acquisition, a new feature in this type of experiment. We vary the names of applicants to signal ethnicity and find that minority names are about half as likely to receive an invitation for an apartment viewing or a job interview. The novel finding is that minority names affect the likelihood of resumes being read on the labor market as well as an applicant's personal website being inspected on the housing market, but the effects are opposite across the two markets. These results support the model's assumption of endogenous attention, which magnifies the role of prior beliefs in discrimination. The model implies persistence of discrimination in selection decisions, even if information about individuals is available and there are no differences in preferences, lower returns to employment qualifications for negatively stereotyped groups, and for policy, the important role of the timing of when a group attribute is revealed.
\end{abstract}

JEL Classification: C93, D83, J15, J71

Keywords: inattention, discrimination, field experiment, information acquisition monitoring

\footnotetext{
* The research was supported by a grant from the CERGE-EI Foundation under a program of the Global Development Network and by the Czech Science Foundation (13-20217S). We thank Martin Gregor, Christian Hellwig, Štěpán Jurajda, Peter Katušćák, Marti Mestieri, Ron Oaxaca, Franck Portier, Chris Sims, Jakub Steiner, Matthias Sutter for valuable comments and Vít Hradil, Iva Pejsarová, Lenka Švejdová and Viktor Zeisel for excellent research assistance.

\# Corresponding author: CERGE-EI, Politických vězňů 7, 11121 Prague 1, Czech Republic; Fax: (+420) 224005 333; Tel.: (+420) 605808 435; Email: bauer@ cerge-ei.cz

$\dagger$ CERGE-EI is a joint workplace of the Center for Economic Research and Graduate Education, Charles University, and the Economics Institute of Academy of Sciences of the Czech Republic.

Address: CERGE-EI, P.O. Box 882, Politických vězňů 7, Prague 1, 111 21, Czech Republic
} 


\begin{abstract}
Abstrakt
V této studii jsou propojeny dvě důležité myšlenky: pozornost je vzácná a zdrojem diskriminace ve výběrových řízeních může být nedostatek informací o daném uchazeči. Představujeme model, který ukazuje, jak je míra pozornosti k dostupným informacím o uchazeči ovlivněna jeho etnickým původem. Model predikuje, že je-li na daném trhu přijímána jen malá část uchazečů, negativní stereotypy vedou k nižší pozornosti. Efekt je opačný v případě, kdy je přijímána většina uchazečů. Tuto "diskriminaci ve věnované pozornosti" testujeme pomocí dvou terénních experimentů. Emailem jsme reagovali na nabídky práce a nabídky nájemního bydlení a současně využili nového prvku v tomto typu experimentů - měření míry akvizice informací. Použitá jména uchazečů signalizují různou etnicitu. K signalizaci původu uchazečů jsme použili jména s různým etnickým vyzněním. Výsledky ukazují, že jména typická pro etnické minority mají poloviční šanci získat pozvánku k prohlídce bytu nebo na pracovní pohovor. Novým poznatkem je, že př́slušnost k minoritě ovlivňuje, zda na trhu práce budou zaměstnavatelé vůbec číst životopis uchazeče a na trhu s nájemním bydlením pronajímatelé otevřou jeho osobní internetové stránky. Efekty jsou na těchto dvou trzích opačné, což je v souladu s endogenní pozorností předpokládanou v našem modelu. Ta zesiluje roli stereotypů o charakteristikách jednotlivce z minoritní skupiny v diskriminačním chování vůči němu. $Z$ modelu vyplývá, že diskriminace ve výběrových řízeních přetrvává $\mathrm{i} v$ př́padě, kdy jsou informace o jednotlivcích dostupné a neexistují rozdíly v preferencích. Model dále poukazuje na nižší výnosy z pracovní kvalifikace u skupin s negativními stereotypy a na důležitost načasování okamžiku, kdy je ve výběrovém řízení zveřejněna citlivá charakteristika uchazeče, např́klad jeho etnický původ.
\end{abstract}




\section{INTRODUCTION}

Understanding why people discriminate based on ethnicity, gender or other observable group attributes has been one of the central topics in economics and other social sciences for decades. ${ }^{1}$ Since the seminal work of Phelps (1972), it has been widely acknowledged that, due to a lack of individual-level information, decision makers often rely on a group attribute as a signal of unobserved individual characteristics. This may give rise to "statistical discrimination" in decisions of whether to hire, rent an apartment, provide a loan or admit an individual to a university, to name a few examples. ${ }^{2}$ At the same time, a large body of research in both economics and psychology shows that scarce attention plays an important role in decision making (e.g., Newell, et al. 1958, Kahneman 1973, Sims 2003, Gabaix, et al. 2006, Mackowiak and Wiederholt 2009). While the existing models of statistical discrimination implicitly assume that individuals are fully attentive to available information, we link the two important literatures. We develop a model in which we describe how knowledge of ethnicity ${ }^{3}$ impacts the level of attention to information about an individual and how the resulting asymmetry in acquired information across groups-denoted "attention discrimination" — can lead to discrimination in a selection decision. We test the model with two correspondence field experiments, which monitor the decision maker's information acquisition about applicants.

Attention to available information about candidates is a crucial input in virtually any selection process. The Economist (2012), for example, describes the process as follows: "They [human resource staff] look at a CV for ten seconds and then decide whether or not to continue reading. If they do, they read for another 20 seconds, before deciding again whether to press on, until there is either enough interest to justify an interview or to toss you into the 'no' pile.". The recent influential field experiment in the U.S. labor market by Bertrand and Mullainathan (2004) finds that returns to sending higher-quality resumes, in terms of callbacks, are higher for applicants with a White-sounding name compared to applicants with

\footnotetext{
${ }^{1}$ Researchers have produced a vast amount of evidence documenting discriminatory behavior based on ethnicity or gender. For a comprehensive survey of regression-based (non-experimental) evidence see Yinger (1998) and Altonji and Blank (1999); for a survey of the audit literature see Riach and Rich (2002); List and Rasul (2011) provide a recent summary of related field experiments.

${ }^{2}$ Taste-based discrimination is the second prominent explanation for why people discriminate (Becker 1971). It arises due to preferences, not due to lack of information. For a comprehensive survey of existing theories of discrimination, both taste-based and statistical, see Lang and Lehmann (2012).

${ }^{3}$ In this paper we focus on discrimination against ethnic minorities, but similar considerations apply to discrimination based on gender, race, age, or other easily observable attributes.
} 
an African-American-sounding name. The pattern is consistent with lexicographic searches: employers stop reading once they see an African-American name on a resume, thus resulting in greater discrimination among more qualified applicants. Methodologically, this work highlights the need to find more direct tools to measure the effect of name on reading effort, and, conceptually, the interpretation of the findings opens the question (Bandiera, et al. 2011) whether such heuristics for inspecting applicants arise unconsciously, as suggested by research in social psychology (e.g., Bertrand, et al. [2005], Stanley, et al. [2008]), and/or due to a choice guided by the expected benefits of reading, as indicated by the qualitative description from practitioners.

To illustrate how allocation of attention and statistical discrimination interact, we propose a new model. First, acquiring information is costly and decision makers optimize how much information to acquire based on the expected net benefits. This leads to "attention discrimination". Second, imperfect information affects selection decisions because the less the decision maker knows about an individual, the more he relies on observable group attributes when assessing individual quality. Putting these two key features together, the endogenous attention magnifies the impact of prior beliefs about group quality, and discrimination in selection decisions can persist even if perfect information about an individual is readily available, if it is equally difficult to screen individuals from dissimilar groups and if there are no differences in taste.

The model provides the following testable implication. On markets where only top applicants are selected from a large pool of candidates (e.g., much of the labor market, admission to top schools, the scientific review process in leading scholarly journals), decision makers should favor acquiring information about individuals from a group that looks a priori "better," while on markets where most applicants are selected (e.g., the rental housing market, admissions to nearly open-access schools), decision makers benefit more from acquiring information about individuals from a group with negative stereotypes.

To test the predictions of the model, we perform two field experiments. We use a correspondence field experiment methodology and send emails responding to apartmentrental advertisements and to job openings in the Czech Republic. We study discrimination against ethnic minorities and randomly vary the names of fictitious applicants. A Whitesounding name signals ethnic-majority status, while Asian- and Roma-sounding names signal ethnic minority status. We use a novel design that measures two types of outcomes: decisions, 
i.e., whether an applicant was invited for a viewing/interview, and the amount and type of information acquired about each applicant prior to the invitation decision. To monitor information acquisition on the housing market, landlords are given an opportunity to click on a hyperlink located in the email from an applicant and learn more on his personal website. On the labor market, employers receive an email application for a job opening, which contains a hyperlink to a resume. We monitor whether landlords and employers actually open the applicant's website (resp. resume) and how many pieces of information they acquire.

We find strong evidence of discrimination faced by minority applicants on both markets. On the housing market, the invitation rate for an apartment viewing is $78 \%$ for applicants with a majority-sounding name, but only $41 \%$ for applicants with a minoritysounding name. The level of discrimination is very similar for applicants with Asian-sounding or Roma-sounding names. On the labor market, applicants with majority-sounding names are invited for a job interview in $13 \%$ of cases. The likelihood diminishes to $8 \%$ for applicants with a Roma-sounding name and further to 5\% for applicants with an Asian-sounding name.

We also find that the name affects the attention given to the available information. On the housing market, landlords acquire more information about applicants with minoritysounding names: landlords are more likely to open their personal website and they are also more likely to uncover information about the applicant's occupation, conditional on opening the website. On the labor market, employers are least likely to open a resume from applicants with an Asian-sounding name and they are also least likely to closely inspect their qualifications, conditional on opening the resume. Together, the results indicate that on the housing market decision makers acquire more information about applicants who, based on their name, look a priori less attractive, while on the labor market attention allocation follows the opposite pattern: decision makers acquire less information about a priori less attractive applicants.

The results provide the first direct evidence of the name type affecting not only the decision whether to invite, but also the form of imperfect information prior to the decision. Further, since the relative level of attention seems to be determined by the market type, rather than by the type of group only, the full set of results cannot be explained by lower attention to minorities due to unconscious reasons (Stanley, et al. 2008) or by the expectation that the available information is less informative (Cornell and Welch 1996). The observed "switch" in relative attention across markets is consistent with the proposed model of statistical 
discrimination with endogenous attention. On the housing market, where the overall invitation rate is high, the benefits of inspection are greater for groups with low expected quality, while the opposite holds on the labor market.

In addition to being consistent with findings from our experiments, the attention discrimination model can help to explain why negatively stereotyped groups may face low returns to employment resume quality - the above-mentioned pattern has been observed for African-Americans on the U.S. labor market (Bertrand and Mullainathan 2004) and for minority groups in Sweden (Bursell 2007), which, in turn, may create gaps in the incentives to acquire human capital. Our model also implies that the timing of when a group attribute is revealed to a decision maker matters. This is because the earlier a decision maker learns about a stereotyped group attribute, the larger the asymmetry in attention to subsequent information. This theoretical result suggests that subtle changes in the initial stages of the selection processes, e.g., postponing when the decision maker learns about a stereotyped group attribute (Goldin and Rouse 2000), may affect discrimination in ultimate decisions.

Our model of attention discrimination contributes to existing theories of discrimination (for a recent survey see Lang and Lehmann [2012]). It is related most closely to "screening discrimination" (Cornell and Welch 1996), in which the key assumption is that it is more difficult to understand signals from a culturally dissimilar group (Lang 1986). Also, social psychologists have argued (for references see Stanley, et al. [2008]) that due to negative unconscious attitudes-“implicit discrimination"-people often use simple decision rules biased against negatively stereotyped groups, which may result in little effortful scrutiny of relevant information. In our model, differences in acquired knowledge are an outcome of the agent's choice and can arise even if the provided signals are equally informative across groups and there are no unconscious biases in attention. This approach relates our model to growing literature on rational inattention that uses an optimizing framework to study the effects of limited attention to the available information on a range of (mostly macroeconomic) phenomena (e.g., Sims [2003], Mackowiak and Wiederholt [2009], Woodford [2009], Mackowiak and Wiederholt [2010], Nieuwerburgh and Veldkamp [2010], Matějka and Sims [2011], Matějka and McKay [2012], Caplin and Dean [2013]).

The empirical part of the paper is related to previous field experiments, which use minority-sounding names in applications, to estimate discrimination on the labor market (Jowell and Prescott-Clarke 1970, Bertrand and Mullainathan 2004) and the rental housing 
market (Ahmed and Hammarstedt 2008, Bosch, et al. 2010, Hanson and Hawley 2011). They consistently find that minority-sounding names lead to lower invitations for a job interview or apartment viewing. ${ }^{4}$ Our experimental design offers a methodological contribution, motivated by providing a sharper test of the proposed model (Card, et al. 2011). In laboratory settings, computer-based monitoring of information acquisition, typically using "Mouselab" software, has been fruitfully used to sort through alternative theoretical explanations of observed behavior (Camerer, et al. 1993, Costa-Gomes, et al. 2001, Gabaix, et al. 2006). ${ }^{5}$ In the field, the role of inattention to information has been studied indirectly (DellaVigna 2009), by estimating the effect of manipulating the salience or content of the provided information on behavior (e.g., Chetty, et al. [2009]). To the best of our knowledge, ours is the first study that integrates the monitoring of information acquisition into a natural field experiment. ${ }^{6,7}$

The rest of the paper is organized as follows. In Section II we develop a model of an inattentive agent who decides how much to learn about an applicant and describe how "attention discrimination" can arise and its implications for discrimination in selection decisions. We also formulate testable predictions for the field experiments. Sections III and IV detail the experimental designs and present empirical results on the rental housing and labor markets. Section V provides a discussion about how the results map on to the proposed model and alternative interpretations. Section VI concludes and closes with a brief discussion of policy implications.

\section{The Model OF ATTENTION DiscriminAtion}

We model a decision maker's (DM) binary choice about an applicant. The applicant is of an inherent quality $q$, which is unknown to the DM. The more attention the DM pays to the applicant

\footnotetext{
${ }^{4}$ Fryer and Levitt (2004) is an interesting example of a non-experimental study in which distinctively AfricanAmerican names are used to analyze the link between names and various life outcomes.

${ }^{5}$ When using Mouselab, researchers display information hidden in boxes on the computer screen and then track which and how many pieces of information subjects acquire. Mouselab software is not the only process tracking technique. For example, Ericsson and Simon (1980) record people "talking aloud" while thinking and Russo and Rosen (1975) or Just and Carpenter (1976) record eye movements. Camerer and Johnson (2004) provide a nice overview about how progress in testing new behavioral approaches has been facilitated by methods that allow the measurement of how people think and what information they acquire (called "process" data).

${ }^{6}$ Here we follow the classification scheme of experiments from Harrison and List (2004).

${ }^{7}$ Our effort to better inform theories of discrimination by collecting novel types of data and performing experiments across distinct markets relates our work to List (2004), who combines a natural field experiment with artefactual field experiments to distinguish between taste-based and statistical discrimination on a product market and to Gneezy, et al. (2012), who measure discrimination based on disability, gender, race and sexual orientation across several markets to understand how the controllability of a group attribute affects discrimination.
} 
the better knowledge of the quality he acquires, but doing so is costly. Let the DM maximize the expected payoff less the cost of information, where the structure of the DM's payoffs is as follows:

$$
\text { payoff }= \begin{cases}q & \text { if the DM accepts the applicant } \\ 0 & \text { if the DM rejects the applicant }\end{cases}
$$

Accepting the applicant generates a payoff that is equal to the applicant's quality, while rejecting the applicant generates a payoff that is normalized to zero without loss of generality; it is a payoff from entertaining a reservation option. ${ }^{8}$

The DM faces two choices. First, he chooses how much attention to pay to the applicant, which determines the precision of his knowledge about $q$, e.g. whether and in how much detail to read the applicant's resume. Second, he decides whether to accept the applicant or not. Except for the DM's choice of attention level, i.e. the endogeneity of the precision of his knowledge about $\mathrm{q}$, the model is analogous to the standard model of statistical discrimination (Phelps 1972).

The DM first observes the applicant's group of ethnic origin $G$. Let us assume that the quality in group $G$ is distributed according to $\mathrm{N}\left(q_{G}, \sigma_{G}^{2}\right)$, which now becomes the DM's prior knowledge about $q$. For our purposes, this is equivalent to assuming that the DM only gets an imperfect signal on the ethnicity, e.g. reads the applicant's name. What matters is the resulting implied form of the knowledge about $q$ only. Next, the DM has an option to receive an additional independent signal $y$ on the applicant's quality such that

$y=q+\varepsilon$,

where $\varepsilon$ is a normally distributed error term, $N\left(0, \sigma_{\varepsilon}^{2}\right) ; \sigma_{\varepsilon}^{2}$ is selected by the DM and it determines the incurred information cost. Then, the DM forms his knowledge according to Bayes law. Upon receiving signals $G$ and $y$ the DM's posterior belief about the quality is given by $N\left(q^{\prime}, \xi \sigma_{G}^{2}\right)$, where

\footnotetext{
${ }^{8}$ The reservation payoff can even describe a continuation value in the case that this single selection decision is a part of a more complicated selection process with more applicants that the DM faces successively. While an increase in the DM's selectivity could be driven by an increase in the reservation payoff, with normalization it is represented by a decrease in the applicants' qualities. The normalization to zero does not change the differences between payoffs for different actions, and thus does not change the DM's actions.
} 


$$
\mathrm{q}^{\prime}=\xi \mathrm{y}+(1-\xi) q_{G}
$$

The weight $\xi=\frac{\sigma_{G}^{2}}{\sigma_{G}^{2}+\sigma_{\varepsilon}^{2}} \in[0,1]$ measures the attention level and also the informativeness of the applicant-specific signal $y$ relative to that of ethnic origin $G$; given $\sigma_{G}^{2}, \xi$ is related one-to-one with $\sigma_{\varepsilon}^{2}$. Equation (1) implies that observing that the applicant belongs to a group with a lower mean quality $q_{G}$ lowers $q^{\prime}$; the lower the attention level $\xi$, the stronger the effect. The DM takes the applicant's ethnic origin into account to the degree of how precise a signal on the applicant's quality it provides relative to other available signals on the quality at hand. Finally, the DM accepts the applicant if and only if the expected quality according to the DM's posterior is higher than the reservation payoff, i.e. $q^{\prime}>0$.

In general, the cost of acquiring information can take many different forms. Let $\xi$ be the DM's choice and let $M(\xi)$ be the cost of information. Let $S \subseteq[0,1]$ be the set of available precision levels, on which the cost $M$ is defined. Let priors and signals take a Gaussian form only.

\section{DEFINITION (the DM's problem)}

Let the DM be endowed with prior knowledge $N\left(q_{G}, \sigma_{G}^{2}\right)$ determined by his knowledge of the applicant's ethnic group, let $\Pi$ be the expected payoff and $M$ be the cost function on the set of achievable precisions $S$. The DM's decision problem is the following. First, the attention level $\xi$ is selected according to:

$$
\max _{\xi \in S} \Pi(\xi)-M(\xi)=\max _{\xi \in S}\left(\frac{1}{\sqrt{2 \pi \xi \sigma_{G}^{2}}} \int_{0}^{\infty} q^{\prime} e^{-\left(q^{\prime}-q_{G}\right)^{2} /\left(2 \xi \sigma_{G}^{2}\right)} d q^{\prime}-M(\xi)\right)
$$

Then, upon receiving the information, the DM accepts the applicant if and only if

$$
\xi q+\xi \varepsilon+(1-\xi) q_{G}>0
$$

where $q$ is the applicant's true quality and $\varepsilon$ is drawn from $N\left(0,(1 / \xi-1) \sigma_{G}^{2}\right)$.

The integral term in equation (2) represents the expected payoff from the accepted applicants for Gaussian uncertainty. Equation (3) expresses q $>0$ using equation (1). From now on we 
assume that $M$ and $S$ are such that an optimal $\xi$ always exists, e.g. $S$ is a finite set, or it is compact and $M$ is continuous.

\section{$\underline{\text { LEMMA } 1 \text { (attention choice) }}$}

The optimal attention $\xi$ is weakly decreasing in the distance $\left|q_{G}\right|$ of the mean quality in group $G$ from the threshold quality. Moreover, if $S=[0,1]$, and if Mis differentiable, then the monotonicity is strict on $(0,1)$.

Proof: Supplementary Material.

The DM acquires more information when it generates a higher payoff. The payoff is higher when it is a priori less clear what the optimal action is, which is when the group's mean quality is closer to the threshold, i.e. when $\left|q_{G}\right|$ is small.

To gain intuition, let us inspect Figure I and let us assume that the specification of $M$ and $S$ is such that the DM faces an observation cost $\lambda$ from observing the quality, $S=\{0,1\}$, $M(0)=0, M(1)=\lambda$. The exhibit on the left shows an example of a prior with a mean that is below the threshold, $q_{G}<0$. The DM would reject the applicant if he did not receive any additional information. The expected quality in the shaded area on the right of the threshold, $E[q \mid q>0]$, is what determines the DM's choice of whether to get the information, i.e. pay $\lambda$, or not. Upon incurring the cost and receiving the perfect information, the DM increases the expected payoff by $\operatorname{Pr}_{(q>0)} * E[q \mid q>0]$ by accepting the applicants above the threshold who would otherwise be rejected. The DM chooses to get the information if and only if this expected gain exceeds the cost, $\lambda$. Similarly, if $q_{G}>0$, which is presented on the right in Figure I, the DM would accept the applicant if he did not receive additional information. The expected gain from acquiring the information is $\operatorname{Pr}_{(q<0)} * E[-q \mid q<0]$, which is driven by rejecting candidates of negative quality that would otherwise be accepted.

In both of these situations, which represent two types of environments differing in the level of DM's selectivity, as the prior moves closer to the threshold as in Lemma 1, the shaded areas in Figure I expand and the expected gain from receiving the information increases. A similar logic holds for other specifications of the cost of information that are used in the literature. In general, the DM could have a choice from two precision levels, e.g. a 
choice of reading the resume completely or not at all, modeled by the observation cost or from a finer or even continuous set of such precisions. ${ }^{9}$

The effects of higher attention on the acceptance probability can be gauged from equation (1), which implies that for group $G$ the posterior means $\mathrm{q}^{\prime}$ are drawn from $N\left(q_{G}, \xi \sigma_{G}^{2}\right)$. Higher attention increases the variance of the posterior means. Lemma 2 then follows immediately.

\section{LEMMA 2 (effect of higher attention)}

If $q_{G}<0$, then a higher attention $\xi$ increases the probability that an applicant from group $G$ is accepted, i.e. that $q^{\prime}>0$. If $q_{G}>0$, then the probability decreases with $\xi$.

Proposition 1 below follows from Lemmas 1 and 2 and describes a new channelcostly attention - through which discrimination can operate. It addresses how beliefs affect attention and also how endogenous attention affects discrimination in the selection decision. We distinguish between two types of markets, i.e. the DM's selection situations: highly selective "cherry-picking" markets where few applicants are accepted and the means of priors for all considered groups are below the threshold, and "lemon dropping" markets with all the means being above the threshold. In the following text we introduce group $P$, an alternative to $G$, which determines a different DM's prior. It can be a group of a different ethnic origin, or even the general population that the applicant is considered to be a member of in case the DM does not receive any signal on the applicant's ethnicity.

\section{PROPOSITION 1 (attention discrimination)}

A) If $\left|q_{G}\right|>\left|q_{P}\right|$, then an applicant from group $G$ is paid (weakly) less attention than an applicant from group $P$ and vice versa.

B) If $q_{G}<q_{P}$, and unless $q_{G}<0<q_{P}$ and $\left|q_{G}\right|<\left|q_{P}\right|$, then the difference in acceptance probability between an applicant from group $P$ and group $G$ is (weakly) higher than if attention $\xi_{G}$ were exogenously fixed at the level of attention $\xi_{P}$ paid to group $P$.

Proof: Supplementary Material.

\footnotetext{
${ }^{9}$ The technology driven by collecting a number of independent Gaussian signals would imply $S=[0,1), M(\xi)=$ $\frac{\lambda}{1-\xi}$, and for rational inattention $S=[0,1), M(\xi)=\lambda \log \frac{1}{1-\xi}$.
} 
Point A of Proposition 1 provides the main testable implication of how beliefs affect attention. It states that the group whose prior mean is closer to the threshold is paid more attention. If the threshold quality changes, ${ }^{10}$ then the distances of the groups' prior means from it change and the ranking of the distances and thus also the ranking of attention levels paid to different groups can change, too. The group with the lower mean is further away from the threshold and thus is paid less attention on a highly selective market where the threshold is above the mean. In contrast, on the "lemon dropping" market, the group with a lower mean is closer to the threshold and it is paid more attention. Other theories of discrimination either assume perfect attention to the available information or imply that the ranking of the quality of the information about the two groups is fixed independent of the market type (as in screening discrimination where groups differ by the precision of signals about them (Cornell and Welch 1996). On the other hand, our model implies that the ranking of attention and the quality of information can be opposite across markets, which is what we test in the experiments.

The attention discrimination driven by differences in the mean qualities of different groups affects the disadvantaged groups more negatively on both the "lemon dropping" and "cherry picking" markets and thus increases discrimination in the selection decisions. According to Lemma 2, if the group mean is below the quality threshold, then more information increases the probability that an applicant is accepted and vice versa. ${ }^{11}$ The disadvantaged group $G$, i.e. $q_{G}<q_{P}$, according to Proposition 1, is paid less attention than group $P$ on highly selective markets-where higher attention increases the probability of acceptance - and more attention on the "lemon dropping" markets where attention decreases the probability of acceptance. The endogenous attention thus increases the difference of the probabilities of acceptance between the two groups relative to when attention $\xi_{G}$ is equal to $\xi_{P}$. The exception is when the mean of $G$ is below the threshold and that of $P$ is above it, i.e. $q_{G}<0<q_{P}$, and if $\left|q_{G}\right|<\left|q_{P}\right|$. Then endogenous attention affects group $G$ more positively than exogenous attention as more attention is paid to $G$ than to $P$; this is when attention is beneficial to $G$ since $q_{G}<0$.

\footnotetext{
${ }^{10}$ This is in our model with the threshold fixed at zero represented by an opposite shift of all quality distributions.

${ }^{11}$ Notice that these findings hold for whole groups only. For instance, an individual of a very high quality on a "lemon dropping" market might be better off when associated with a group of lower mean, since then the DM chooses to pay more attention and can be more likely to notice the individual's high quality.
} 
Understanding whether imperfect knowledge about applicants arises due to a lack of available information, due to an unconscious choice of attention or, as in our model, in line with some optimal decisions can be important for policy considerations. While we do not test the following implications experimentally, they show that if attention is endogenous, then different policies can motivate the DM to pay attention to different ethnic groups and thus determine the final form of imperfect knowledge upon which the DM makes his decision.

\section{$\underline{\text { PROPOSITION } 2 \text { (timing of ethnic group revelation) }}$}

If $q_{G}<q_{P}$, and unless $q_{G}<0<q_{P}$ and $\left|q_{G}\right|<\left|q_{P}\right|$, then the probability that an applicant from group $G$ is accepted is (weakly) lower if he is known to be from G prior to when the DM chooses the precision of signal $y$ (and before he receives y) rather than when he is first considered to be from $P$ and his membership in $G$ is revealed only before the final selection decision.

Proof: Supplementary Material.

Postponing the revelation of the group attribute helps the disadvantaged group by affecting the level of attention the DM pays to the applicant. This effect is not present in the standard model of statistical discrimination, because there the DM receives signals of exogenously given precision and forms his posterior knowledge independent of the signals' succession, while in our model the first signal affects the choice of the precision of the following signal.

Finally, Lemmas 1 and 2 imply that policies increasing the group's quality relative to the DM's threshold have stronger effects when the attention is endogenous. Specifically, if the policy increases the quality of the group, a standard channel for reducing discrimination, then it also triggers an attention response of the DM. On the "cherry-picking" markets, the group is then paid more attention as its quality approaches the threshold (Lemma 1), which further increases the chances of acceptance (Lemma 2). Similarly, on the "lemon-dropping" market, the invitation rate also further increases, but this time because the DM chooses to pay less attention after the policy change.

Our model also provides implications for cases when the variance of beliefs or the costs of information differ across groups. A higher variance of beliefs increases attention and higher costs decrease it. The distinction from Proposition 1, where the groups differ in quality means, is that the ranking of attention levels across groups is then independent of the market 
type, i.e. of the position of the threshold. Group $G$ is either always paid less attention than $P$ or always more.

\section{FIELD EXPERIMENT ON THE RENTAL HOUSING MARKET}

\section{III.A. Experimental Design}

In our first experiment, we study discrimination against Roma and Asian minorities on the rental housing market in the Czech Republic. The Roma population constitutes the largest ethnic minority in the European Union (estimated at 6 million people, 1.2\%) as well as in the Czech Republic (1.5-3\%). Intolerance and social exclusion of Roma is considered one of the most pressing social and human rights issues in the European Union (European Commission 2010). The unemployment rate of Roma in the Czech Republic is estimated at $38 \%$ compared to $9.4 \%$ overall unemployment rate in 2012. East Asians (mostly Vietnamese but also Chinese or Japanese) are the second-largest ethnic minority group in the Czech Republic (0.6\%) and migrants from East Asia form large minority groups in many European countries. In the Czech Republic they are mostly self-employed in trade and sales businesses and lack formal employment. An opinion poll revealed that $86 \%$ and $61 \%$ of Czechs would not feel comfortable or would find it unacceptable to have Roma and Vietnamese as neighbors, respectively. $^{12}$

The experiment was based on sending emails expressing interest in arranging an apartment viewing. To evoke ethnic minority status we designed three fictitious applicants: representatives of the Asian and Roma ethnic minorities and a control identity of the White majority group. The only real attributes of these identities were a name, an email address and a personal website. ${ }^{13}$ When selecting names, we used name frequency data and chose the

\footnotetext{
${ }^{12}$ For more details about the socio-economic status of Roma in Central and Eastern European countries see Barany (2002). For a recent survey, which documents inequalities in education, employment, health and housing outcomes between Roma and majority populations in the Czech Republic and other EU countries, see FRA and UNDP (2012). Spaan, et al. (2005) provide a thorough description of the migration patterns and integration of immigrants from East Asia in Europe.

${ }^{13}$ There is a difficult trade-off involved in organizing a natural field experiment on discrimination. While informed consent is clearly desirable, it is obvious that one cannot measure discrimination with the consent of participants (List and Rasul 2011). Therefore field experiments on discrimination are considered among the prime candidates for the relaxation of informed consent (Riach and Rich 2002, Pager 2007), and this has been the practice of all existing audit and correspondence field experiments on discrimination. Our research has been approved by the management of the Institute of Economic Studies, Charles University in Prague. We also did our best to minimize the landlords' costs. We sent only one application to each landlord and we quickly declined invitations for an apartment viewing, within two days at most. The information acquisition was designed such
} 
following names: Jiří Hájek (White majority-sounding name), Phan Quyet Nguyen (Asiansounding name) and Gejza Horváth (Roma-sounding name). ${ }^{14}$ For the sake of brevity, we denote applicants with a White majority-sounding name as "White applicants" or as "majority applicants", applicants with ethnic minority-sounding names (both Asian and Roma) as "minority applicants", and applicants with Asian-sounding and Roma-sounding names as "Asian applicants" and "Roma applicants", respectively. Note that technically the results of our experiments describe the effects of the ethnic sounding-ness of the names rather than the effects of ethnicity itself. We discuss this distinction in Section V.

To verify that landlords associated the selected names with respective ethnic groups, we conducted a small pre-survey on a sample of 50 respondents. All respondents associated the name Jiří Hájek with the Czech nationality and the name Phan Quyet Nguyen with one of the Asian nationalities (92\% associated it with Vietnamese nationality) and the name Gejza Horváth was thought to be a Roma name in $82 \%$ of cases, indicating a strong link between names and ethnic status. Next, we sent each variant of the email message to 40 individuals with email accounts from different providers. In all cases the emails were delivered successfully, affirming that spam filters do not affect our estimates.

In application emails, we manipulated access to information about applicants. In the No Information Treatment, the email contains a greeting and the applicant's interest in renting an apartment, but does not provide any information about the characteristics of an applicant, other than his minority/majority-sounding name. Next, in the Monitored Information Treatment, the email uses the same sentence to express interest in viewing an apartment. The only difference is that it includes a hyperlink to a personal website located in the applicant's electronic signature, which gives landlords an opportunity to acquire more information about an applicant. The link has a hidden unique ID number assigned to each landlord, which allows us to distinguish landlords who decide to acquire information about the applicant.

The website contains information about individual characteristics that are likely to affect the attractiveness of a prospective tenant: education, employment status, age, marital status and smoking habits. All applicants reported to be 30 years old, single, non-smokers,

that it took little effort and time. A similar practice was followed in our companion experiment on the labor market.

${ }^{14}$ Jiří is the most frequent Czech first name and Hájek is among top 20 most frequent surnames in the Czech Republic. Nguyen and Horváth are the most frequent surnames for the Asian and Roma minorities, respectively. 
having a high school or college degree and working in trade with a steady income. We avoided syntax or spelling mistakes.

Software similar to "Mouselab", specifically developed for this experiment, monitors landlords' information acquisition on the website. Five different boxes are located in the main section of the website, each with a heading representing a type of information that is hidden "behind" the box such as education, job, etc. A snapshot is displayed in Figure II. Since only one box can be opened by a computer mouse at one point in time, the software allows us to identify whether a landlord decides to acquire information on an applicant's website, and how many and which pieces of information receive attention. These monitoring features provide direct insight into the process of information acquisition. The design of the website is based on a professionally created template, which is freely available on the Internet and into which individuals input their own personal information. In addition to the boxes with personal information, the website also contains tags for a personal blog, pictures and contact information (when accessed, an "under construction" note pops up, to reduce landlord's costs by limiting the time spent on the website).

\section{III.B. Sample Selection and Data}

The experiment was implemented between December 2009 and August 2010 in the Czech Republic, mostly in Prague. Over that period, we monitored four (out of ten) major websites that provide rental advertisements. ${ }^{15}$ Placing an ad on these websites requires a small fee, while responding to an advertisement is free. We chose to apply only for small homogenous apartments of up to two rooms with a separate kitchen that look suitable for a single tenant without a family. We excluded offers mediated by real estate agents and focused on offers given by individual landlords because we are interested in the behavior of landlords who will interact directly with tenants. To be able to monitor information acquisition we had to exclude offers where landlords did not make their email publicly available and relied on a telephone or an online form (66\%). Overall, we responded to 1800 rental ads and randomly assigned an applicant name and provided information. We recorded the gender of the landlord, implied by the name, and the characteristics of apartments commonly published as a part of advertisement such as rental price, the size of the apartment and whether it is furnished. These

\footnotetext{
${ }^{15}$ In 2012, 65\% of households had Internet access at home (Czech Statistical Office 2013).
} 
characteristics vary little across experimental treatments, indicating that randomization was successful (Supplementary Table 1).

To measure attention in the Monitored Information Treatment, we record whether a landlord visits an applicant's personal website and how many and which boxes with information he uncovers. To measure responses to the applicant, we distinguish between a positive response, indicating either a direct invitation to an apartment viewing or an interest in further contact, and a negative response, capturing the rejection of an applicant or an absence of response. ${ }^{16}$ Note that with the correspondence experimental approach a researcher does not measure the ultimate outcomes, i.e. whether an applicant rents the apartment and for what price. Nevertheless, we believe that it is plausible that the gaps in the share of positive responses across ethnic groups translate into gaps in final decisions about actual rental.

\section{III.C. Results}

\section{III.C.1. Do Landlords Discriminate Against Minorities?}

We start the analysis by looking at whether ethnic minorities are discriminated against when no information about the applicant other than his name is available to a landlord (No Information Treatment). In this treatment, the invitation rates reflect the tastes and prior beliefs about the expected characteristics of each group. We find that majority applicants are invited for an apartment viewing in $78 \%$ of cases, while minority applicants receive invitations in only $41 \%$ of cases (Panel A of Table I). The gap that arises solely due to name manipulation is large in magnitude (37 percentage points, or 90\%) and statistically significant at the $1 \%$ level. Put differently, minority applicants have to respond to almost twice as many advertisements to receive the same number of invitations as majority applicants.

Next, we distinguish between applicants with Asian- and Roma-sounding names. The invitation rates are very similar: $43 \%$ for the Roma minority and $39 \%$ for the Asian minority applicants. The difference in invitation rate between the two minority groups is not statistically distinguishable (Column 12, Panel A of Table I), while the gap between the

\footnotetext{
${ }^{16}$ As a robustness check, we also estimated the effects of minority-signaling names on callbacks (Supplementary Table 3), which distinguishes applications that result in contact, regardless of whether it is a positive or negative response. Overall, we find qualitatively similar impacts of name on the callback rate as on the invitation rate.
} 
majority and each of the two minority groups is large and similar in magnitude (Columns 7 and 10 of Table I, Column 2 of Table II).

Observation 1: Applicants with minority-sounding names are discriminated against. If no information about applicants is available, applicants with a majority-sounding name are $90 \%$ more likely to be invited for an apartment viewing compared to applicants with a minoritysounding name.

Since in this treatment landlords do not receive any specific characteristics of applicants and make inferences based on the applicant's name (and the short text) only, the decision whether to invite should closely reflect whether the expected quality of an applicant is greater than the threshold quality. Since most majority applicants are invited (78\%), the mean of the prior belief about this group seems to be far above the threshold level of quality necessary for invitation. On the other hand, the lower invitation rate observed for minority applicants, or more precisely an invitation rate closer to $50 \%$, indicates that the mean prior beliefs about the quality of this group is closer to the quality threshold. Thus, acquiring more information about minority applicants should be more valuable, compared to acquiring information about majority applicants.

\section{III.C.2. Do Landlords Choose Different Levels of Attention to Information Based on the} Ethnicity of an Applicant?

In the Monitored Information Treatment, we find that only less than half of the landlords open the applicant's website even though the cost of acquiring information is very small—literally one click on the hyperlink - suggesting that attention is indeed a scarce resource. Importantly, the applicant's name matters for attention allocation (Panel B of Table I). While $41 \%$ of landlords opened the website of minority applicants, 33\% did so for majority applicants and the difference of 8 percentage points ( 24 percent) is statistically significant at $5 \%$ level.

Among landlords who opened an applicant's website, we still observe more effort to acquire information about minority applicants. Landlords open a higher number of boxes with information when the applicants have minority names compared to majority names. This is because landlords are significantly more likely to open the box with information about the 
occupation of minority applicants compared to majority applicants. The effects on opening boxes with other characteristics go in the same direction but are insignificant statistically.

Taken together, the likelihood of acquiring information about, for example, education level is $36 \%$ for minority applicants and $27 \%$ for majority applicants. Thus, the difference due to name manipulation is $33 \%$ (or 9 percentage points). A similar picture arises for other individual characteristics: the likelihood of paying attention to those is $30-46 \%$ greater for minority applicants compared to majority applicants. When summing the number of applicant characteristics to which a landlord pays attention (the maximum is five), we find that landlords learn about 1.75 characteristics of a minority applicant and 1.29 for a majority applicant.

Distinguishing the two minority groups reveals that, compared to the majority applicant, landlords acquire more information about both Roma and Asian applicants (Columns 7 and 10). We also observe that the amount of acquired information is somewhat (although insignificantly) greater for Roma applicants relative to Asian applicants (Column 12). This is interesting given that the landlords appeared to hesitate most on whether to invite Roma applicants, since the invitation rate of this minority was closest to the $50 \%$ invitation rate.

Panel B of Table II reports the results in a regression framework, where we control for the landlord's gender and the characteristics of the apartment described in an advertisement (price, size, furnishings). We arrive at the same conclusion: the likelihood of a landlord visiting an applicant's website and the number of pieces of information acquired is higher for minority applicants compared to majority applicants.

Observation 2: Landlords pay more attention to available information about applicants with a minority-sounding name relative to applicants with a majority-sounding name.

\section{III.C.3. Responsiveness to Available Information}

Does the greater inspection of the personal website of minority applicants compared to majority applicants matter? If it does, then we should observe a greater responsiveness in the invitation rate to manipulations in available information about minority applicants compared to information about the majority applicants, echoing the observed differences in attention. This would not be the case, if, on the other hand, greater attention was due to pure curiosity 
about dissimilar individuals. ${ }^{17}$ To test this, we estimate the responsiveness to three manipulations in the available information: (1) adding a sentence signaling attractive characteristics of the applicant to the email message asking for an apartment viewing ("I am a thirty-year-old man, I am single, I have a college [a high school] degree, and I do not smoke. I have a steady job (with a regular paycheck) at a company."), (2) varying the education level between high-school degree and college degree in the added sentence and (3) having access to an applicant's personal website.

We find that the invitation rate responds to information provided by applicants with minority names, a pattern which is consistent for all three manipulations of available information. Column 8 in Panel A of Table II shows that, relative to the No Information Treatment, the invitation rate increases by 8 percentage points for minority applicants who add the sentence reporting high school education. The increase is larger, 15 percentage points, for minority applicants who add a sentence and report having a college degree. The pure effect of reporting a college degree compared to a high school degree is 8 percentage points, which is marginally significant statistically. Last, giving access to a personal website increases the invitation rate by 8 percentage points. ${ }^{18}$

In contrast, there is little response in the invitation rate when the same manipulations of available information are performed by the applicant with the majority name (Column 7). The invitation rate remains at the same level, $78 \%$, independent of whether the applicant provides no information, includes a sentence about his characteristics, and also does not respond to changes in his education level. Only having access to an applicant's personal website causes a moderate but not statistically significant response: the invitation rate diminishes by 6 percentage points.

Observation 3: The landlords' decision whether to invite an applicant is responsive to manipulations of the available information about applicants with a minority-sounding name, while the decision is not (or only little) affected by the same changes in the available information about applicants with a majority-sounding name.

\footnotetext{
${ }^{17} 93 \%$ of landlords in our sample have a White majority-sounding name.

${ }^{18}$ Landlords are responsive to changes in available information about both minority groups; see Supplementary Table 4.
} 
Last, in the Monitoring Information Treatment, we consider whether the observed differences in the amount of acquired information across groups affect the size of the gap in the invitations rate. In Columns 3 and 5 in Panel A of Table II, we show that controlling for opening an applicant's website increases the effect of the minority name from $23 \%$ to $26 \%$ (the difference in coefficients is not significant statistically). Although the resulting change is not very large in magnitude (13\% of the gap), perhaps because our measure of information acquisition is still a crude proxy of attention, it illustrates how choices of attention affect discrimination in selection decisions. Given that the website provides a positive signal about applicant's quality, the endogenous attention reduces discrimination in this setting.

To summarize the main results on the rental housing market, we find that a name affects both the choices of whether to invite an applicant for an apartment viewing as well as the attention paid to information prior to this decision. Applicants with minority-sounding names are more thoroughly inspected and less likely to be invited for an apartment viewing. Differences in the observed level of inspection across the groups mimic greater responsiveness of the invitation rate to the manipulation of available information about the quality of applicants with minority-sounding names.

\section{FIELD EXPERIMENT ON THE LABOR MARKET}

Our second experiment shifts the exploration of discrimination to the labor market. Here, we aim to study discrimination during a selection process in which decision makers pick only a few winners out of a large pool of applications, in contrast to the rental housing market. As described in Section II, the theory gives contrasting predictions about the relative attention paid to majority and minority groups across the two types of markets.

\section{IV.A. Experimental Design}

We use the same names as in the rental housing market experiment to evoke Asian, Roma and White majority ethnic status. The experiment was implemented between August and October 2012 in the Czech Republic. Over that period we monitored the major online job site (www.jobs.cz) and responded to online job advertisements. We implement the treatment with the monitoring of information acquisition, and send an application via email. The email contains a greeting, the applicant's interest in the job opening, his name and a hyperlink to his professional resume on a website. The exact wording is in the Supplementary Material. 
We created a conventional resume, following real-life resumes for the types of jobs we study. Each has six parts: education, experience, skills, hobbies, references and contacts. Applicants are 23-year-old males, with a high school or a college degree, and have prior work experience as administrative workers. They report a good knowledge of English, PC skills and a driver's license. They also list their hobbies and provide two reference contacts.

When they open the website, employers can see a standard version of the resume. Further, they can click on "learn more" buttons placed below each resume category label (contact, education, experience, skills and hobbies). For example, when the website is accessed it reveals basic information about previous employment experience: the name of the firm, the position held and the time period. By clicking on the "learn more" button below the "Experience" label, the website reveals the applicant's responsibilities (e.g., document management, administrative support of consultants, work with PC). Thus, in addition to monitoring whether an employer opens the resume, we measure whether an employer decides to acquire more and which type of information. An example of the shorter as well as the expanded form of the resume is in Figure III.

\section{IV.B. Sample Selection and Data}

We focused on job openings in sales, customer service and administrative work. We selected these job categories because they have a sufficient flow of new openings and are similar enough not to require subtle adjustments of particular skills in resumes. In addition, we aimed to minimize the costs for the employers of reviewing the resumes and thus we selected job categories that involve less intensive inspection of applicants compared to higher-skill jobs. We also sent only one email to each employer and politely declined all invitations for job interviews within two days.

We target the population of employers who use the Internet to advertise job openings, ${ }^{19}$ and we exclude newspapers and other more informal channels of job openings. To be able to monitor the opening of an applicant's resume, we had to exclude ads in which employers did not make their email publicly available and required applicants to call or use an online form (59\%). Overall, we responded to 274 job openings and to each of them we

\footnotetext{
${ }^{19}$ In 2010 in the Czech Republic, 43\% of all unemployed people searched on the Internet for a job. Among people with university education the rate was $73 \%$ and among people with high school education it was $65 \%$. At the same time, there were twice as many employed people searching on the Internet for a job compared to the total number of unemployed people using the Internet to search for a job (Czech Statistical Office 2013).
} 
randomly assigned the name of an applicant. We record the type of job, the job requirements and the time when the application was sent. Supplementary Table 5 reports the means of the observable characteristics of job openings across the three groups of applicants. The means are similar, with the exception of a somewhat higher likelihood of majority applicants applying for openings that required previous job experience, compared to minority applicants (p-value $=0.13)$ and the lower likelihood of majority applicants applying during the holiday period ( $\mathrm{p}$-value $=0.12$ ). In the analysis, we rely on a comparison of means across treatment conditions, as well as a regression analysis in which we control for observable characteristics.

We study how the name manipulation affects the two types of choices: attention to a resume and the selection decision. First, we measure whether an employer opened an applicant's resume by clicking on the hyperlink to a resume website. Further, we identify which additional information about an applicant an employer uncovered by clicking on the "learn more" buttons. As was the case of the first experiment, we do not measure the ultimate outcome of a selection process (an actual employment offer and wage). The outcome measure is whether the employer emailed or called the applicant back with a decision ("callback") and whether the employer decided to invite the applicant for an interview ("invitation"), a more precise outcome of the initial stage of selection process than callback. ${ }^{20}$

\section{IV.C. Results}

\section{IV.C.1. Are Ethnic Minorities Less Likely to be Invited for a Job Interview?}

Panel A of Table III documents a large amount of discrimination against minority applicants. The callback rate for majority applicants is $43 \%$ and only $20 \%$ for minority applicants, making a difference of more than $100 \%$, which is highly significant statistically $(\mathrm{p}<0.01)$. A similar picture arises when we turn to the invitation rate. While majority applicants are invited in $14 \%$ of cases, minority applicants receive an invitation only in $6.3 \%$ of cases. The gap is statistically significant $(\mathrm{p}$-value $=0.03)$ and is large in magnitude $(133 \%)$.

\footnotetext{
${ }^{20}$ Since the application was sent via email, the most common response from employers was also via email: $25.9 \%$ of employers emailed back, $9.1 \%$ invited the applicant for an interview and $16.8 \%$ declined the application. Employers could also call the applicant's cell phone since each applicant reported a functional cell phone number as a part of the resume and the number was different for each ethnic group. However, only a few employers called back (5.8\%). We recorded "missed calls" on each cell phone and then called back to determine the particular employer. Since most of the employers who made a phone call also responded via email and one employer sent a text message with an invitation; in only six cases we cannot directly identify whether the employer who called back meant to invite the applicant or not. In the main estimations we assume they did not, given the large fraction of declines in the email responses and the fact that these employers did not get in touch with the applicant via email.
} 
While we observe the almost identical treatment of applicants with Roma- and Asiansounding names on the rental housing market, we find some differences on the labor market. Both minority groups are less likely to be invited for a job interview compared to the majority group. The gap, however, is larger and more significant statistically for the Asian minority applicant $(5.1 \%$ invitation rate, $\mathrm{p}$-value $=0.03)$ than the gap for the Roma minority applicant $(7.8 \%$ invitation rate, $p$-value $=0.18)$. Put differently, Asian applicants need to send 20 applications to receive one invitation, Roma applicants 12.5 and majority applicants 7.5. Columns 1-4 in Panel A of Table IV demonstrate the evidence in a regression framework. Controlling for observable job characteristics-required high school education, required previous experience, the type of job, and whether the application was sent during the summer holidays - does not affect the size of the observed gaps in the invitation rates and somewhat increases precision. We also find that employers who decide to read a resume are more likely to invite the applicant (Column 5) and those who request previous job experience are less likely to invite the applicant (not reported, available upon request). ${ }^{21}$

Observation 4: Applicants with minority-sounding names are discriminated against on the labor market. An applicant with a majority-sounding name is $180 \%$ more likely to be invited for a job interview compared to an applicant with an Asian-sounding name and $75 \%$ more likely compared to an applicant with a Roma-sounding name.

The invitation rate (on average 9.1\%) on the labor market is much lower than $50 \%$, despite the fact that the resume signals the relatively high quality of applicants for the selected types of job. If we were to link this observation to theory, it would imply that mean prior beliefs about the quality of all groups are below the threshold necessary for an interview invitation and that the labor market is the "cherry-picking" type of market. ${ }^{22}$ Resumes of applicants with minority names, and with Asian names in particular, are thus predicted to receive less attention compared to resumes provided by majority applicants.

\footnotetext{
${ }^{21}$ It is noteworthy that discrimination is not restricted to jobs where language skills and interactions with customers are central (sales and services), and thus employers could presumably discriminate due to a belief about language use or due to the expected taste-based discrimination of their customers (Supplementary Table 7).

${ }^{22}$ Low invitation rates seem to be a ubiquitous feature of labor markets. The invitation rates do not get anywhere close to $50 \%$ in any segment of the market, which does not allow us to test the theoretical prediction about the "switch" in relative attention between minority and majority groups within one type of market (in contrast to testing it across two different markets, as we do in this paper).
} 
IV.C.2. Do Employers Choose Different Levels of Attention to Information Based on the Ethnicity of an Applicant?

We start by looking at the likelihood of opening a resume. 58\% of employers open the resume. ${ }^{23}$ Name again matters. We find that while $63.3 \%$ of employers visit the webpage with a resume of majority applicants, only $47.5 \%$ of employers do so when they receive an application with the Asian-minority name. The difference is large in magnitude (34\%) and significant statistically (Panel B of Table III and Panel B of Table IV) and it demonstrates that ethnicity signaled by name represents a barrier even at the very start of a selection process, before any information about an applicant is acquired. Moreover, in some firms it is common to delegate the printing of all received applications to an assistant, and printed resumes are then screened and evaluated by a different person. In such cases our experimental design fails to measure differences in attention, biasing down the estimated effect of a name on the likelihood of opening a resume. Regarding Roma-minority applicants, i.e. the group with the invitation rate between the majority and the Asian minority applicants, we find no discrimination in attention: the likelihood of opening the resume is the same as for the majority applicant and higher compared to the Asian-minority applicant (Column 2 in Panel B of Table IV).

Further, we study whether employers differentiate attention after opening the resume. Overall, we find relatively little interest to acquire further information; only $23 \%$ of employers clicked on at least one out of five "learn more" buttons. Despite the relatively little variation, the data reveal that employers paid less attention to the qualifications of Asian minority applicants. Specifically, when considering majority applicants, 16\% of employers further inspected at least one out of three categories that seem relevant for assessing qualification (experience, education and skills), while only 6\% made that effort when considering Asian minority applicants (Panel B of Table III). We find no differences in acquiring information about contacts and hobbies.

In sum, the Asian minority, i.e. the group with the lowest invitation rate, receives the least attention, which is in line with the predictions of our model of attention discrimination. Since the invitation rate of the Roma minority applicant is lower than the invitation rate of the majority applicant and higher than the invitation rate of the Asian minority applicant, the

\footnotetext{
${ }^{23}$ The fact that $37 \%$ of employers did not open the resume of majority applicants indicates, for instance, that some of the openings were filled before the advertisement we responded to was withdrawn from the online job site.
} 
model predicts that the amount of acquired information about the Roma applicant should also be somewhere between the Asian applicant and the White applicant. Nevertheless, we do not observe any differences in attention compared to the majority applicant.

Observation 5: Employers are 34\% more likely to read a resume provided by applicants with majority-sounding names relative to applicants with Asian-sounding names. Conditional on opening a resume, employers more closely inspect the qualifications of applicants with a majority-sounding name relative to applicants with an Asian-sounding name. There is little difference in the likelihood of opening a resume as well as in the depth of resume inspection between applicants with majority- and Roma-sounding names.

Last, since reporting an Asian-sounding name reduces attention to the resume provided by the applicant and at the same time resume reading correlates strongly with the invitation rate, we explore whether differences in attention allocation can explain part of the discrimination in the decision of whether to invite the candidate for an interview or not. Indeed, the effect of an Asian-sounding name on invitation rates diminishes once we control for whether an employer reads a resume, from 8.1 percentage points to 6.6 percentage points, indicating a reduction of discrimination of around $20 \%$ (the difference in coefficients is not statistically significant). The magnitude of discrimination reduction should, however, be considered with caution. Our measure of attention is likely to be imprecise since it does not capture the intensity of information processing; also, in some firms, assistants automatically print incoming resumes for human resource managers who make choices whether or not to read them.

\section{Alternative EXPLANATIONS}

We now consider which models of discrimination can explain the findings from the field experiments, specifically the observed gaps in invitation rates for an apartment viewing as well as a job interview, and the contrasting effects of an applicant's name on information acquisition on the labor and housing markets (employers give the least attention to a resume from an Asian minority, who is the least likely to be invited, while landlords pay more attention to personal websites of applicants with minority-sounding names). 
The existing statistical discrimination models, in which decision makers use an observable group attribute to form beliefs about mean unobservable individual quality (Phelps 1972, Arrow 1973), can explain the lower invitation rates of minority applicants on both markets. Nevertheless, since attention is exogenous in these models, they cannot explain the effects of the name on the amount of acquired information. Introducing endogenous attention, as developed in Section II, explains the full set of empirical findings. On the housing market the overall invitation rate is high, thus the benefits of inspection are greater for groups with low expected quality, while on the labor market, where firms select only a few top applicants, the expected benefits of reading a resume is smallest for the group with the lowest expected quality.

Purely taste-based models of discrimination (Becker 1971) can explain why minorities receive fewer invitations on both markets, but they are mute about why there are differences in attention to available information. Nevertheless, it should be noted that our results do not rule out the existence of taste-based discrimination on the markets we study. Our findings are consistent with discriminatory behavior motivated partly by differences in preferences and partly by differences in beliefs about average quality combined with endogenous attention.

Next, we consider the psychological concept of implicit discrimination that relies on an unconscious bias to explain why people discriminate and pay less attention to negatively stereotyped groups. This approach can explain differences in invitation rates and also less reading of resumes with Asian minority names on the labor market, but it fails to account for why on the rental housing market a minority name increases the amount of acquired information and the responsiveness to manipulations of the applicant's quality. The relative level of attention seems to be co-determined by the selectivity of the market, rather than by the group only.

Another class of statistical discrimination models emphasizes a lower precision of observable signals from culturally dissimilar groups as a source of discrimination (Aigner and Cain 1977, Cornell and Welch 1996). This approach does not explicitly consider how a lower precision of available signals affects attention, but the corresponding decision on attention level could be described in our model by assuming that the costs of information is higher for minorities. If decision makers expect such differences in costs, they should acquire less information about minorities, in line with the observed pattern on the labor market, but contrary to the results on the rental housing market. In principle, the "switch" in relative 
attention across markets could be explained if the expected precision of the available signals switched, too, i.e. if landlords expected it to be cheaper to become informed about minorities, while employers expected the same about majorities. Although we do not rule this explanation out, we do not find it appealing as it introduces an additional degree of freedom without a clear motivation.

In sum, while some of the existing models of discrimination are consistent with less information acquisition about minority groups on the labor market, none of them predicts the observed switch in relative attention to groups across labor and housing markets, except for the proposed "attention discrimination". An alternative explanation for the observed greater inspection of personal websites of minority applicants on the housing market could be pure curiosity to read about dissimilar individuals, not motivated by assessment of quality for selection decisions. We think this explanation is unlikely because (1) the correlation between opening a website and inviting is similar or greater for minority applicants compared to majority applicants (Supplementary Table 8), (2) the observed differences in attention across groups mimic observed differences in responsiveness to manipulations of available information and (3) the effect of a minority name is largest on uncovering occupation information (compared to age, education, smoking habits, and marital status), arguably a very relevant characteristic for assessing the ability to pay rent and thus for a selection decision.

Although the selected names used in this experiment strongly signal ethnicity, they may also signal some other group attributes, social background in particular. Due to this limitation, as is common for these types of correspondence field experiments, it is difficult to infer whether decision makers in our experiment are discriminating against ethnicity or social background. It should be noted, however, that since the predictions of our model are independent of which particular group attribute gives rise to differences in beliefs, this is not a limitation in terms of testing whether differences in attention exist and whether they follow theoretical predictions for an attention-optimizing agent.

\section{CONCLUding REMARKS}

One of the main insights of information economics is that even very small frictions in information acquisition can have large effects on economic outcomes (Diamond 1971, Sims 2003). At the same time, imperfect information is central to explaining discrimination on markets since the seminal work of Phelps (1972) and Arrow (1973). Yet there is no theory or 
direct evidence studying how the small costs of information acquisition may create differences in the form of imperfect information about individuals based on their observable group attributes. This is what we provide.

We take seriously the fact that reading the details of applications for a job, an apartment rental, loans or school admission is costly. In the model that we propose, the decision makers choose how much attention to pay to an applicant based on his observable group attributes. We show that "attention discrimination"-different attention given to different groups - can drive discrimination in selection processes. If the level of attention is subject to choice, as in our model, then it can change depending on the desired level of the quality of applicants that the decision maker would like to accept. The model predicts that negative stereotypes about a group lower attention to the group when the decision maker's selectivity is high. On the other hand, the negative stereotype is associated with high attention to the group when selectivity is low.

To test the model, we perform two natural field experiments. We send applications responding to job openings and to advertisements for apartment rentals and study how a name that signals the applicant's ethnicity affects the amount of acquired information and the probability of receiving an invitation. We find that applicants with a minority-sounding name are invited less for an apartment viewing as well as for a job interview compared to applicants with a majority-sounding name. Although it seems extremely easy for decision makers to acquire information, we show that they do not acquire all the available information and that the name of the applicant influences the amount of information acquired. Groups with low invitation rates are inspected more on the rental market, where most applicants are invited. At the same time, on the labor market, in which only top applicants are selected, employers are less likely to read resumes provided by members of the group with a low invitation rate. The observed "switch" in relative attention to different groups across these markets is in line with the proposed model, in which decision makers adjust attention based on expected benefits and cannot be explained by a bias in attention due to unconscious reasons or by the expectation of a relatively lower clarity of available information about one of the groups.

In addition to presenting novel empirical findings, the experimental design distinguishes itself by offering a methodological contribution. Our analysis joins efforts in laboratory settings to test decision-making processes with enhanced measurement tools, in particular by monitoring information acquisition (Costa-Gomes, et al. 2001, Camerer and 
Johnson 2004, Gabaix, et al. 2006). We show that the widespread use of the Internet by economic decision makers opens the possibility of collecting "process data" as a part of a natural field experiment as well. By this, researchers can study in greater detail the processes taking place inside the "black box" and can better inform theories and policy-makers on issues, including those that are sensitive and hard to study in the laboratory (Levitt and List 2007), of which discrimination is one important example.

The theoretical contribution of the "attention discrimination" approach is the illustration that the availability of information is not the only aspect of interest. The decision maker must also be willing to process the information at hand. As a result, discrimination in the selection of applicants can arise even when the decision makers have the same preferences across different groups, when all the relevant information is available and when obtaining information about different groups is equally difficult. Prior beliefs about ethnic groups in our model enter the final decision not only through Bayesian updating, as in the standard model of statistical discrimination, but also through the choice of attention level, and thus have the potential for a larger impact on discrimination. Our model also suggests a new mechanism as to why negatively stereotyped groups may face lower returns to higher quality resumes during the hiring stage on the labor market, a pattern which has been consistently documented in previous field experiments (Bertrand and Mullainathan 2004, Bursell 2007). It predicts that decision makers pay less attention to applicants from negatively stereotyped groups on highly selective markets and thus differentiate less based on their quality. Given that highly competitive selections mark an individual's career from early school years to the labor market, we speculate that this mechanism may contribute to lowering incentives to acquire human capital in the first place and thus perpetuates gaps in human capital across groups.

We close by discussing the policy implications of the model. The model speaks to the debate about affirmative action policies, such as tax rebates or other benefits to employing negatively stereotyped groups. Such policies lower the threshold necessary for acceptance, a standard channel for reducing discrimination, but, if attention is endogenous, they should also trigger a leveling of attention across groups, which further reinforces equalization of selection probabilities across different groups. Next, and perhaps more interestingly, the model implies the important role of the timing of when a group attribute is revealed and how the selection process is organized. Since the earlier a decision maker learns a group attribute, such as name, the larger the asymmetry in attention to subsequent information such as education or qualification, the theory strengthens the case for suppressing the signals of a group attribute 
during early pre-selection. In this context it is intriguing that among policy-makers and private firms, the introduction of name-blind resumes has been receiving support during recent years, ${ }^{24}$ in part because researchers produced evidence indicating that blind auditioning (Goldin and Rouse 2000) and name-blind resumes (Skans and Åslund 2012) can reduce discrimination. Also, the model provides merit for thinking about the separate rankings of applicants from non-minority and minority groups (or across gender lines) followed by a comparison of leading candidates across the groups. One can think of this rule as providing quotas for the outcomes of early pre-selection. It is perhaps worth noting that while such antidiscriminatory rules impose constraints on access to information and choices during the beginning of the selection process, they preserve the freedom of the final selection decision. We hope these implications will motivate further empirical work.

\section{Author affiliations}

Vojtěch Bartoš

CERGE-EI, a joint workplace of Charles University and the Economics Institute of the Academy of Sciences of the Czech Republic; Politických vězňů 7, 11121 Prague, Czech Republic

\section{Michal Bauer}

CERGE-EI, a joint workplace of Charles University and the Economics Institute of the Academy of Sciences of the Czech Republic; Politických vězňu 7, 11121 Prague, Czech Republic

Charles University, Faculty of Social Sciences, Institute of Economic Studies; Opletalova 26, Prague 1, 110 00, Czech Republic

\section{Julie Chytilová}

Charles University, Faculty of Social Sciences, Institute of Economic Studies; Opletalova 26, Prague 1, 110 00, Czech Republic

\footnotetext{
${ }^{24}$ Name-blind resumes have recently been implemented for hiring workers in the public sector in Belgium, the Netherlands and Sweden. The policy is being piloted in Germany among several major companies, including Deutsche Post, Deutsche Telekom, L'Oréal and Procter \& Gamble.
} 


\section{Filip Matějka}

CERGE-EI, a joint workplace of Charles University and the Economics Institute of the Academy of Sciences of the Czech Republic; Politických vězňů 7, 11121 Prague, Czech Republic 


\section{REFERENCES}

Ahmed, Ali, and Mats Hammarstedt, "Discrimination in the Rental Housing Market: A Field Experiment on the Internet," Journal of Urban Economics, 64 (2008), 362-372.

Aigner, Dennis J., and Glen G. Cain, "Statistical Theories of Discrimination in Labor Markets," Industrial and Labor Relations Review, 30 (1977), 175-187.

Altonji, Joseph G., and Rebecca M. Blank, "Race and Gender in the Labor Market," in Handbook of Labor Economics, Orley C. Ashenfelter, and David Card, eds. (Elsevier, 1999).

Arrow, Kenneth, "The Theory of Discrimination," in Discrimination in Labor Markets, Orley Ashenfelter, and Albert Rees, eds. (Princeton, N.J.: Princeton University Press, 1973).

Bandiera, Oriana, Iwan Barankay, and Imran Rasul, "Field Experiments with Firms," Journal of Economic Perspectives, 25 (2011), 63-82.

Barany, Zoltan, The East European Gypsies: Regime Change, Marginality, and Ethnopolitics (Cambridge University Press, 2002).

Becker, Gary S., The Economics of Discrimination (Chicago: University of Chicago Press, 1971).

Bertrand, Marianne, Dolly Chugh, and Sendhil Mullainathan, "Implicit Discrimination," American Economic Review, 95 (2005), 94-98.

Bertrand, Marianne, and Sendhil Mullainathan, "Are Emily and Greg More Employable Than Lakisha and Jamal? A Field Experiment on Labor Market Discrimination," American Economic Review, 94 (2004), 991-1013.

Bosch, M., M. Carnero, and L. Farré, "Information and Discrimination in the Rental Housing Market: Evidence from a Field Experiment," Regional Science and Urban Economics, 40 (2010), 11-19.

Bursell, Moa, "What's in a Name? A Field Experiment Test for the Existence of Ethnic Discrimination in the Hiring Process," (Stockholm University, mimeo, 2007).

Camerer, Colin F., and Eric Johnson, "Thinking About Attention in Games: Backward and Forward Induction," in Psychology of Economic Decisions, Isabel Brocas, and Juan Carillo, eds. (New York: Oxford University Press, 2004).

Camerer, Colin F., Eric Johnson, Talia Rymon, and Sankar Sen, "Cognition and Framing in Sequential Bargaining for Gains and Losses," in Frontiers of Game Theory, Ken G. Binmore, Alan P. Kirman, and Piero Tani, eds. (MIT Press, 1993).

Caplin, Andrew, and Mark Dean, "Rational Inattention and State Dependent Stochastic Choice," (NYU, mimeo, 2013).

Card, David, Stefano DellaVigna, and Ulrike Malmendier, "The Role of Theory in Field Experiments," Journal of Economic Perspectives, 25 (2011), 39-62. 
Chetty, Raj, Adam Looney, and Kory Kroft, "Salience and Taxation: Theory and Evidence," American Economic Review, 99 (2009), 1145-1177.

Cornell, Bradford, and Ivo Welch, "Culture, Information, and Screening Discrimination," Journal of Political Economy, 104 (1996), 542-571.

Costa-Gomes, Miguel, Vincent P. Crawford, and Bruno Broseta, "Cognition and Behavior in Normal-Form Games: An Experimental Study," Econometrica, 69 (2001), 1193-1235.

Czech Statistical Office, http://www.czso.cz/eng/redakce.nsf/i/home (2013).

DellaVigna, Stefano, "Psychology and Economics: Evidence from the Field," Journal of Economic Literature, 47 (2009), 315-372.

Diamond, Peter A., "A Model of Price Adjustment," Journal of Economic Theory, 3 (1971), 156-168.

Ericsson, K. Anders, and Herbert A. Simon, "Verbal Reports as Data," Psychological review, 87 (1980), 215-251.

European Commission, "The Social and Economic Integration of the Roma in Europe," http://eur-lex.europa.eu/LexUriServ/LexUriServ.do?uri=COM:2010:0133:FIN:EN:PDF (2010).

FRA (European Union Agency for Fundamental Rights), UNDP, "The Situation of Roma in 11 EU Member States: Survey Results at a Glance," http://fra.europa.eu/sites/default/files/fra_uploads/2099-FRA-2012-Roma-at-a-glance_EN.pdf (2012).

Fryer, Roland G, and Steven D Levitt, "The Causes and Consequences of Distinctively Black Names," The Quarterly Journal of Economics, 119 (2004), 767-805.

Gabaix, Xavier, David Laibson, Guillermo Moloche, and Stephen Weinberg, "Costly Information Acquisition: Experimental Analysis of a Boundedly Rational Model," American Economic Review, 96 (2006), 1043-1068.

Gneezy, Uri, John List, and Michael K. Price, "Towards an Understand of Why People Discriminate: Evidence from a Series of Natural Field Experiments," NBER Working Paper No. 17855, 2012.

Goldin, Claudia, and Cecilia Rouse, "Orchestrating Impartiality: The Impact of 'Blind' Auditions on Female Musicians," American Economic Review, 90 (2000), 715-741.

Hanson, Andrew, and Zackary Hawley, "Do Landlords Discriminate in the Rental Housing Market? Evidence from an Internet Field Experiment in US Cities," Journal of Urban Economics, 70 (2011), 99-114.

Harrison, Glenn W., and John A. List, "Field Experiments," Journal of Economic Literature, 42 (2004), 1009-1055.

Jowell, Roger, and Patricia Prescott-Clarke, "Racial Discrimination and White-Collar Workers in Britain," Race \& Class, 11 (1970), 397-417. 
Just, Marcel Adam, and Patricia A. Carpenter, "Eye Fixations and Cognitive Processes," Cognitive Psychology, 8 (1976), 441-480.

Kahneman, Daniel, Attention and Effort (Prentice Hall, 1973).

Lang, Kevin, "A Language Theory of Discrimination," Quarterly Journal of Economics, 101 (1986), 363-382.

Lang, Kevin, and Jee-Yeon K. Lehmann, "Racial Discrimination in the Labor Market: Theory and Empirics," Journal of Economic Literature, 50 (2012), 959-1006.

Levitt, Steven D., and John A. List, "What Do Laboratory Experiments Measuring Social Preferences Reveal About the Real World?," Journal of Economic Perspectives, 21 (2007), 153-174.

List, J. A., "The Nature and Extent of Discrimination in the Marketplace: Evidence from the Field*," Quarterly Journal of Economics, 119 (2004), 49-89.

List, John A., and Imran Rasul, "Field Experiments in Labor Economics," Handbook of Labor Economics, 4 (2011), 103-228.

Mackowiak, Bartosz Adam, and Mirko Wiederholt, "Business Cycle Dynamics under Rational Inattention ," Center for Economic Policy Research Working Paper No. 7691, 2010.

Mackowiak, Bartosz, and Mirko Wiederholt, "Optimal Sticky Prices under Rational Inattention," American Economic Review, 99 (2009), 769-803.

Matějka, Filip, and Alisdair McKay, "Simple Market Equilibria with Rationally Inattentive Consumers," American Economic Review, 102 (2012), 24-29.

Matějka, Filip, and Christopher A. Sims, "Discrete Actions in Information-Constrained Tracking Problems," CERGE-EI Working Paper No. 441, 2011.

Newell, Allen, John C. Shaw, and Herbert A. Simon, "Elements of a Theory of Human Problem Solving," Psychological Review, 65 (1958), 151-166.

Nieuwerburgh, Stijn Van, and Laura Veldkamp, "Information Acquisition and underDiversification," Review of Economic Studies, 77 (2010), 779-805.

Pager, Devah, "The Use of Field Experiments for Studies of Employment Discrimination: Contributions, Critiques, and Directions for the Future," The Annals of the American Academy of Political and Social Science, 609 (2007), 104-133.

Phelps, Edmund S., "The Statistical Theory of Racism and Sexism," American Economic Review, 62 (1972), 659-661.

Riach, Peter A., and Judy Rich, "Field Experiments of Discrimination in the Market Place," Economic Journal, 112 (2002), 480-518.

Russo, J. Edward, and Larry D. Rosen, "An Eye Fixation Analysis of Multialternative Choice," Memory and Cognition, 3 (1975), 267-276. 
Sims, Christopher A., "Implications of Rational Inattention," Journal of Monetary Economics, 50 (2003), 665-690.

Skans, Oskar Nordström, and Olof Åslund, "Do Anonymous Job Application Procedures Level the Playing Field?," Industrial and Labor Relations Review, 65 (2012).

Spaan, Ernst, Felicitas Hillmann, and Ton van Naerssen, Asian Migrants and European Labour Markets: Patterns and Processes of Immigrant Labour Market Insertion in Europe (Taylor \& Francis, 2005).

Stanley, Damian, Elizabeth A. Phelps, and Mahzarin Benaji,"The Neural Basis of Implicit Attitudes," Current Directions in Psychological Science, 17 (2008), 164-117.

The Economist, "Ask the expert: How to write a CV," http://www.economist.com/whichmba/ask-expert-how-write-cv (2012).

Woodford, Michael, "Information-Constrained State-Dependent Pricing," Journal of Monetary Economics, 56 (2009), S100-S124.

Yinger, John, "Evidence on Discrimination in Consumer Markets," Journal of Economic Perspectives, 12 (1998), 23-40. 
Table I

Rental Housing Market - Invitation Rates and Information Acquisition by Ethnicity, Comparison of Means

\begin{tabular}{|c|c|c|c|c|c|c|c|c|c|c|c|c|}
\hline & $\begin{array}{c}\text { White } \\
\text { majority } \\
\text { name }(W) \\
\end{array}$ & & & & Ethnic n & minority & y name & & & & & \\
\hline & (1) & $\begin{array}{l}\text { Pooled } \\
\text { Asian and } \\
\text { Roma } \\
\text { minority } \\
\text { name (E) } \\
(2)\end{array}$ & $\begin{array}{c}\text { Ratio: } \\
\text { W/E } \\
(3)\end{array}$ & $\begin{array}{c}\text { p.p. } \\
\text { difference: } \\
\text { W-E, } \\
\text { (p-value) } \\
\text { (4) }\end{array}$ & $\begin{array}{c}\text { Asian } \\
\text { minority } \\
\text { name } \\
\text { (A) } \\
\text { (5) }\end{array}$ & $\begin{array}{l}\text { Ratio: } \\
\text { W/A } \\
\text { (6) }\end{array}$ & $\begin{array}{c}\text { p.p. } \\
\text { difference: } \\
\text { W-A, } \\
\text { (p-value) } \\
\text { (7) }\end{array}$ & $\begin{array}{c}\text { Roma } \\
\text { minority } \\
\text { name } \\
\text { (R) } \\
(8)\end{array}$ & $\begin{array}{l}\text { Ratio: } \\
\text { W/R } \\
\text { (9) }\end{array}$ & $\begin{array}{c}\text { p.p. } \\
\text { difference: } \\
\text { W-R, } \\
\text { (p-value) } \\
(10)\end{array}$ & $\begin{array}{c}\text { Ratio: } \\
\text { R/A } \\
\text { (11) }\end{array}$ & $\begin{array}{c}\text { p.p. } \\
\text { difference: } \\
\text { R-A, } \\
\text { (p-value) } \\
(12)\end{array}$ \\
\hline \multicolumn{13}{|l|}{ Panel A: Invitation for an apartment viewing } \\
\hline No Information Treatment & $\begin{array}{c}0.78 \\
(0.41)\end{array}$ & $\begin{array}{c}0.41 \\
(0.49)\end{array}$ & 1.90 & $\begin{array}{c}37 \\
(\mathbf{0 . 0 0 )})\end{array}$ & $\begin{array}{c}0.39 \\
(0.49)\end{array}$ & 2.00 & $\begin{array}{c}39 \\
(0.00)\end{array}$ & $\begin{array}{c}0.43 \\
(0.50)\end{array}$ & 1.81 & $\begin{array}{c}36 \\
(0.00)\end{array}$ & 1.10 & $\begin{array}{c}3 \\
(0.57)\end{array}$ \\
\hline \multicolumn{13}{|l|}{ Monitored Information Treatment } \\
\hline - all observations in this treatment & $\begin{array}{c}0.72 \\
(0.45)\end{array}$ & $\begin{array}{c}0.49 \\
(0.50)\end{array}$ & 1.47 & $\begin{array}{c}23 \\
(\mathbf{0 . 0 0})\end{array}$ & $\begin{array}{c}0.49 \\
(0.50)\end{array}$ & 1.47 & $\begin{array}{c}23 \\
(\mathbf{0 . 0 0})\end{array}$ & $\begin{array}{c}0.49 \\
(0.50)\end{array}$ & 1.47 & $\begin{array}{c}23 \\
(0.00)\end{array}$ & 1.00 & $\begin{array}{c}0 \\
(0.92)\end{array}$ \\
\hline - sub-sample of landlords who opened applicant's website & $\begin{array}{c}0.84 \\
(0.37) \\
\end{array}$ & $\begin{array}{c}0.66 \\
(0.48)\end{array}$ & 1.27 & $\begin{array}{c}18 \\
(0.00) \\
\end{array}$ & $\begin{array}{c}0.71 \\
(0.46)\end{array}$ & 1.18 & $\begin{array}{c}13 \\
(0.04) \\
\end{array}$ & $\begin{array}{c}0.62 \\
(0.49)\end{array}$ & 1.35 & $\begin{array}{c}21 \\
(0.00) \\
\end{array}$ & 0.87 & $\begin{array}{c}-9 \\
(0.20)\end{array}$ \\
\hline \multicolumn{13}{|l|}{ Panel B: Information acquisition } \\
\hline Likelihood of opening applicant's personal website & $\begin{array}{c}0.33 \\
(0.47)\end{array}$ & $\begin{array}{c}0.41 \\
(0.49)\end{array}$ & 0.80 & $\begin{array}{c}-8 \\
(0.03)\end{array}$ & $\begin{array}{c}0.38 \\
(0.49)\end{array}$ & 0.87 & $\begin{array}{c}-5 \\
(0.24)\end{array}$ & $\begin{array}{c}0.44 \\
(0.50)\end{array}$ & 0.75 & $\begin{array}{c}-11 \\
(0.01)\end{array}$ & 1.16 & $\begin{array}{c}6 \\
(0.15)\end{array}$ \\
\hline \multicolumn{13}{|l|}{ Number of pieces of information acquired } \\
\hline - all observations in the Monitored Information Treatment & $\begin{array}{c}1.29 \\
(2.06)\end{array}$ & $\begin{array}{c}1.75 \\
(2.24)\end{array}$ & 0.74 & $\begin{array}{l}-0.46^{\mathrm{a}} \\
(0.01)\end{array}$ & $\begin{array}{c}1.61 \\
(2.21)\end{array}$ & 0.80 & $\begin{array}{l}-0.32^{a} \\
(0.09)\end{array}$ & $\begin{array}{c}1.88 \\
(2.27)\end{array}$ & 0.69 & $\begin{array}{l}-0.59^{a} \\
(0.00)\end{array}$ & 1.17 & $\begin{array}{l}0.27^{\mathrm{a}} \\
(0.17)\end{array}$ \\
\hline - sub-sample of landlords who opened applicant's website & $\begin{array}{c}3.91 \\
(1.62)\end{array}$ & $\begin{array}{c}4.24 \\
(1.28)\end{array}$ & 0.92 & $\begin{array}{l}-0.33^{a} \\
(0.06)\end{array}$ & $\begin{array}{c}4.23 \\
(1.31)\end{array}$ & 0.92 & $\begin{array}{l}-0.32^{\mathrm{a}} \\
(0.15)\end{array}$ & $\begin{array}{c}4.25 \\
(1.26)\end{array}$ & 0.92 & $\begin{array}{l}-0.34^{\mathrm{a}} \\
(0.09)\end{array}$ & 1.00 & $\begin{array}{l}0.02^{\mathrm{a}} \\
(0.90)\end{array}$ \\
\hline
\end{tabular}

Notes: Means. Standard deviations in parentheses. Panel A reports the likelihood of invitation for an apartment viewing for applicants with the White-majority sounding name (Column 1), a minority-sounding name (pooled Asian and Roma minority name, Column 2), the Asian-sounding name (Column 5), and the Roma-sounding name (Column 8),

The table report ratios (Columns 3, 6, 9) and differences (Columns 4, 7, 10) in the invitation rate for White majority and respective minority groups. In the parentheses in Columns 3, 6, 9 we report p-value for a t-test testing the null hypothesis that the invitation rates are equal for applicants with a White-majority sounding name and a respective minority-sounding name. Columns 11 and 12 report the ratio and difference for the Asian and Roma minority applicants. Panel B reports how name affects information acquisition in the Monitored Information Treatment - the likelihood of opening a personal website and the amount of acquired information. ${ }^{\text {a }}$ The difference in the number of pieces of information acquired on the website across names is reported in absolute terms, not in percentage points. 
Table II

Rental Housing Market - Invitation Rates and Information Acquisition by Ethnicity, Regression Analysis

Panel A: Landlord's selection decision

\section{Dependent variable:}

Sample:

Ethnic minority name

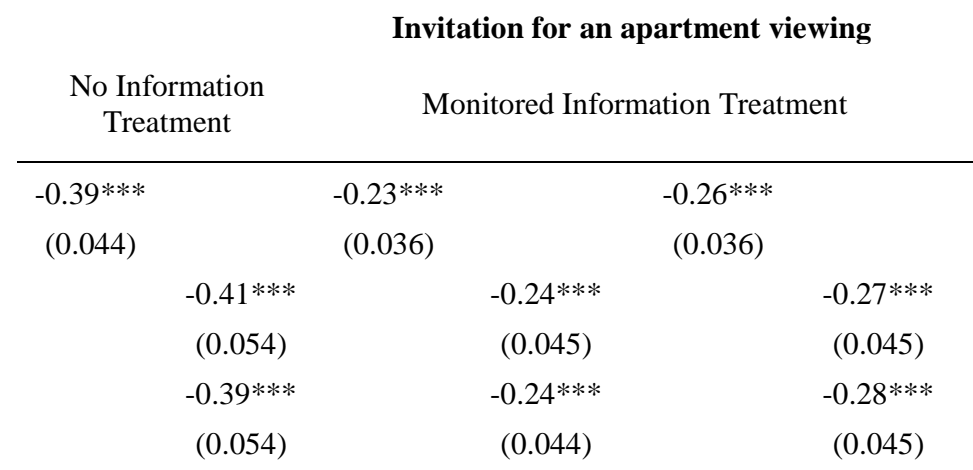

Monitored Information Treatment

Additional text in the email - with high school

Additional text in the email - with college

White Ethnic

majority minority

Asian minority name

$(0.044)$

(0.045)

$\begin{array}{cc}-0.06 & 0.08 * * \\ (0.045) & (0.036) \\ -0.00 & 0.08^{*} \\ (0.056) & (0.046) \\ 0.01 & 0.15 * * \\ (0.058) & (0.046) \\ & \end{array}$

Opening applicant's website 451 \begin{tabular}{lll}
451 & $762 \quad 762$ \\
\hline
\end{tabular}

$\begin{array}{cc}0.26 * * * & 0.26 * * * \\ (0.036) & (0.036)\end{array}$

Observations A landlord opens 762 762 $599 \quad 1,194$

Panel B: Information acquisition

\section{Dependent variable: \\ Sample: \\ Ethnic minority name}

Asian minority name

\section{A landlord opens applicant's perso
webpage}

Monitored Information Treatment observations

Acquiring
Acquiring information personal

\begin{tabular}{|c|c|c|c|c|c|}
\hline \multicolumn{3}{|c|}{$\begin{array}{c}\text { Monitored Information Treatment - all } \\
\text { observations }\end{array}$} & \multicolumn{3}{|c|}{$\begin{array}{l}\text { Monitored Information Treatment - sub-sample } \\
\text { of landlords who opened applicant's website }\end{array}$} \\
\hline $0.08 * *$ & & & $0.18 * *$ & & \\
\hline$(0.037)$ & & & $(0.085)$ & & \\
\hline & 0.05 & 0.31 & & $0.17 *$ & 0.07 \\
\hline & $(0.045)$ & $(0.192)$ & & $(0.098)$ & $(0.141)$ \\
\hline
\end{tabular}


Notes: Probit, marginal effects $(\mathrm{dF} / \mathrm{dx})$ in all columns of Panel $\mathrm{A}$, and Columns 1, 2 of Panel B. OLS in Columns 3-8 of Panel B. Robust standard errors in parentheses. *** denotes significance at the $1 \%$ level, $* *$ at the $5 \%$ level and * at the $10 \%$ level. In Panel A, the dependent variable is the invitation rate. In Panel B, the dependent variable is a dummy variable indicating whether a landlord opened applicant's personal website (Columns 1-2), the number of pieces of information he/she uncovered on applicant's personal website - minimum is 0 and maximum is 5 (columns 3-4), the number of pieces of information about education and occupation he/she uncovered - minimum is 0 and maximum is 2 (Columns 5-6), and the number of pieces of information about personal characteristics (age, smoking habits, marital status) he/she uncovered - minimum is 0 and maximum is 3 (Columns 7-8). In Columns 1-6 of Panel A and all columns of Panel B the omitted variable is the White-majority name. In Columns 7-8 of Panel A the omitted variable is a dummy for No Information Treatment. In all columns of both panels, we control for a dummy variable indicating a landlord being a female, a dummy variable indicating an unknown gender of a landlord (the mean of this variable in the whole sample as well as in the Monitored Information Treatment is 0.02 ), size of an apartment, price of an apartment rental, and a dummy variable indicating a furnished apartment. 
Table III

Labor Market - Invitation Rates and Information Acquisition by Ethnicity, Comparison of Means

\begin{tabular}{|c|c|c|c|c|c|c|c|c|c|c|c|c|}
\hline & $\begin{array}{c}\text { White } \\
\text { majority } \\
\text { name }(W)\end{array}$ & & & & Ethni & ic minol & ity name & & & & & \\
\hline & $(1)$ & $\begin{array}{c}\text { Pooled } \\
\text { Asian and } \\
\text { Roma } \\
\text { minority } \\
\text { name (E) } \\
(2) \\
\end{array}$ & $\begin{array}{c}\text { Ratio: } \\
\text { W/E } \\
\text { (3) }\end{array}$ & $\begin{array}{c}\text { p.p. } \\
\text { difference: } \\
\text { W-E, } \\
\text { (p-value) } \\
(4)\end{array}$ & $\begin{array}{c}\text { Asian } \\
\text { minority } \\
\text { name } \\
(\mathrm{A}) \\
(5) \\
\end{array}$ & $\begin{array}{c}\text { Ratio: } \\
\text { W/A } \\
(6)\end{array}$ & $\begin{array}{c}\text { p.p. } \\
\text { difference: } \\
\text { W-A, } \\
\text { (p-value) } \\
(7)\end{array}$ & $\begin{array}{c}\text { Roma } \\
\text { minority } \\
\text { name }(\mathbf{R}) \\
(8)\end{array}$ & $\begin{array}{l}\text { Ratio: } \\
\text { W/R } \\
\text { (9) }\end{array}$ & $\begin{array}{c}\text { p.p. } \\
\text { difference: } \\
\text { W-R, } \\
\text { (p-value) } \\
(10) \\
\end{array}$ & $\begin{array}{l}\text { Ratio: } \\
\text { R/A } \\
(11) \\
\end{array}$ & $\begin{array}{c}\text { p.p. } \\
\text { difference: } \\
\text { R-A, } \\
\text { (p-value) } \\
(12) \\
\end{array}$ \\
\hline \multicolumn{13}{|l|}{ Panel A: Employer's response } \\
\hline Callback & $\begin{array}{c}0.43 \\
(0.50)\end{array}$ & $\begin{array}{c}0.20 \\
(0.40)\end{array}$ & 2.15 & $\begin{array}{c}23 \\
(\mathbf{0 . 0 0 )}\end{array}$ & $\begin{array}{c}0.17 \\
(0.38)\end{array}$ & 2.53 & $\begin{array}{c}26 \\
(0.00)\end{array}$ & $\begin{array}{c}0.25 \\
(0.43)\end{array}$ & 1.72 & $\begin{array}{c}18 \\
(0.01)\end{array}$ & 1.47 & $\begin{array}{c}8 \\
(0.22)\end{array}$ \\
\hline \multicolumn{13}{|l|}{ Invitation for a job interview } \\
\hline - all observations & $\begin{array}{c}0.14 \\
(0.35)\end{array}$ & $\begin{array}{c}0.06 \\
(0.24)\end{array}$ & 2.33 & $\begin{array}{c}8 \\
(0.03)\end{array}$ & $\begin{array}{c}0.05 \\
(0.22)\end{array}$ & 2.80 & $\begin{array}{c}9 \\
(\mathbf{0 . 0 3})\end{array}$ & $\begin{array}{c}0.08 \\
(0.27)\end{array}$ & 1.75 & $\begin{array}{c}6 \\
(0.18)\end{array}$ & 1.59 & $\begin{array}{c}3 \\
(0.46)\end{array}$ \\
\hline - sub-sample of employers who opened applicant's resume & $\begin{array}{c}0.19 \\
(0.40) \\
\end{array}$ & $\begin{array}{c}0.09 \\
(0.29) \\
\end{array}$ & 2.11 & $\begin{array}{c}10 \\
(0.06) \\
\end{array}$ & $\begin{array}{c}0.09 \\
(0.28) \\
\end{array}$ & 2.11 & $\begin{array}{c}10 \\
(0.12) \\
\end{array}$ & $\begin{array}{c}0.10 \\
(0.30) \\
\end{array}$ & 1.90 & $\begin{array}{c}9 \\
(0.16) \\
\end{array}$ & 1.11 & $\begin{array}{c}1 \\
(0.83) \\
\end{array}$ \\
\hline \multicolumn{13}{|l|}{ Panel B: Information acquisition } \\
\hline Likelihood of opening applicant's resume & $\begin{array}{c}0.63 \\
(0.48)\end{array}$ & $\begin{array}{c}0.56 \\
(0.50)\end{array}$ & 1.13 & $\begin{array}{c}7 \\
(0.22)\end{array}$ & $\begin{array}{c}0.47 \\
(0.50)\end{array}$ & 1.34 & $\begin{array}{c}16 \\
(0.03)\end{array}$ & $\begin{array}{c}0.66 \\
(0.48)\end{array}$ & 0.95 & $\begin{array}{c}-3 \\
(0.69)\end{array}$ & 1.41 & $\begin{array}{c}19 \\
(0.01)\end{array}$ \\
\hline $\begin{array}{l}\text { Qualification - likelihood of acquiring more information } \\
\text { about education, experience or skills } \\
\text { - sub-sample of employers who opened applicant's } \\
\text { resume }\end{array}$ & $\begin{array}{c}0.16 \\
(0.37)\end{array}$ & $\begin{array}{c}0.10 \\
(0.30)\end{array}$ & 1.60 & $\begin{array}{c}6 \\
(0.27)\end{array}$ & $\begin{array}{c}0.06 \\
(0.25)\end{array}$ & 2.67 & $\begin{array}{c}10 \\
(0.12)\end{array}$ & $\begin{array}{c}0.14 \\
(0.35)\end{array}$ & 1.14 & $\begin{array}{c}2 \\
(0.73)\end{array}$ & 2.33 & $\begin{array}{c}8 \\
(0.24)\end{array}$ \\
\hline $\begin{array}{l}\text { Other information - likelihood of acquiring more } \\
\text { information about hobbies or contact } \\
\text { - sub-sample of employers who opened applicant's } \\
\text { resume }\end{array}$ & $\begin{array}{c}0.18 \\
(0.39)\end{array}$ & $\begin{array}{c}0.18 \\
(0.39)\end{array}$ & 1.00 & $\begin{array}{c}0 \\
(0.92)\end{array}$ & $\begin{array}{c}0.19 \\
(0.40)\end{array}$ & 0.95 & $\begin{array}{c}-1 \\
(0.85)\end{array}$ & $\begin{array}{c}0.18 \\
(0.39)\end{array}$ & 1.00 & $\begin{array}{c}0 \\
(0.99)\end{array}$ & 0.94 & $\begin{array}{c}1 \\
(0.85)\end{array}$ \\
\hline
\end{tabular}

Notes: Means. Standard deviations in parentheses. Panel A reports the likelihood of callback and the likelihood of invitation for a job interview for applicants with the Whitemajority sounding name (Column 1), a minority-sounding name (pooled Asian and Roma minority name, Column 2), the Asian-sounding name (Column 5), and the Romasounding name (Column 8). The table reports the ratios (Columns 3,6,9) and differences (Columns 4, 7, 10) of these variables for the White majority and respective minority groups. In the parentheses in Columns 3, 6, 9 we report p-value for a t-test testing the null hypothesis that the callback and invitation rates are equal for applicants with a White-majority sounding name and a respective minority-sounding name group. Columns 11 and 12 report the ratio and difference for Asian and Roma minority applicants. Panel B reports the likelihood of opening an applicant's resume and the likelihood of clicking on "learn more" buttons in a resume (to acquire more information about a particular resume sub-category). The comparison across groups is the same as in Panel A. 
Table IV

Labor Market - Invitation Rate and Information Acquisition by Ethnicity, Regression Analysis

\begin{tabular}{|c|c|c|c|c|c|c|}
\hline & $(1)$ & (2) & (3) & (4) & (5) & (6) \\
\hline \multicolumn{7}{|c|}{ Panel A: Employers' response } \\
\hline Dependent variable: & \multicolumn{2}{|c|}{ Callback } & \multicolumn{4}{|c|}{ Invitation for a job interview } \\
\hline Sample: & \multicolumn{2}{|c|}{ All } & \multicolumn{4}{|c|}{ All } \\
\hline \multirow[t]{2}{*}{ Ethnic minority name } & $-0.23 * *$ & & $-0.09 * * *$ & & $-0.08 * *$ & \\
\hline & $(0.06)$ & & $(0.04)$ & & $(0.036)$ & \\
\hline \multirow[t]{2}{*}{ Asian minority name } & & $-0.24 * * *$ & & $-0.08 * *$ & & $-0.07 * *$ \\
\hline & & $(0.05)$ & & $(0.03)$ & & $(0.03)$ \\
\hline \multirow[t]{2}{*}{ Roma minority name } & & $-0.16^{* *}$ & & $-0.06^{*}$ & & $-0.05 *$ \\
\hline & & $(0.06)$ & & $(0.03)$ & & $(0.03)$ \\
\hline \multirow[t]{2}{*}{ Opening applicant's resume } & & & & & $0.08 * * *$ & $0.08 * * *$ \\
\hline & & & & & $(0.03)$ & $(0.03)$ \\
\hline Observations & 274 & 274 & 274 & 274 & 274 & 274 \\
\hline
\end{tabular}

Panel B: Information acquisition

\section{Dependent variable}

Sample:

Ethnic minority name

Asian minority name

Roma minority name

Observations

ions $\quad 274 \quad 274$ applicant's resume

All

0.03

Acquiring more Acquiring more

information about information about qualification other characteristics

Employers who open applicant's resume

$\begin{array}{lcc}-0.08 & -0.07 & -0.01 \\ (0.06) & (0.06) & (0.064)\end{array}$

$\begin{array}{lll}-0.16^{* *} & -0.10^{*} & -0.00 \\ (0.07) & (0.05) & (0.08)\end{array}$

$-0.03$

$-0.02$

(0.08)

(0.06)

$(0.07)$

160

160

160

Notes: Probit, marginal effects $(\mathrm{dF} / \mathrm{dx})$, robust standard errors in parentheses. $* * *$ denotes significance at the $1 \%$ level, $* *$ at the $5 \%$ level and $*$ at the $10 \%$ level. In Panel A, the dependent variable is the callback (Columns 1-2) and the invitation rate (Columns 3-6). In Panel B, the dependent variable is a dummy variable indicating whether an employer opened applicant's resume (Columns 1-2), whether he/she uncovered additional information about applicant's qualification - education, experience, or skills (Columns 3-4), and whether he/she uncovered additional information about hobbies and contacts (Columns 5-6). In all columns of both panels, the omitted variable is the White majority name and we control for dummy variables indicating required high school education, required previous experience, application being sent during a holiday period (August), and application in the sector of sales and services. 
Figure I

Expected Benefits from Information Acquisition on Two Markets of Different Selectivity Levels

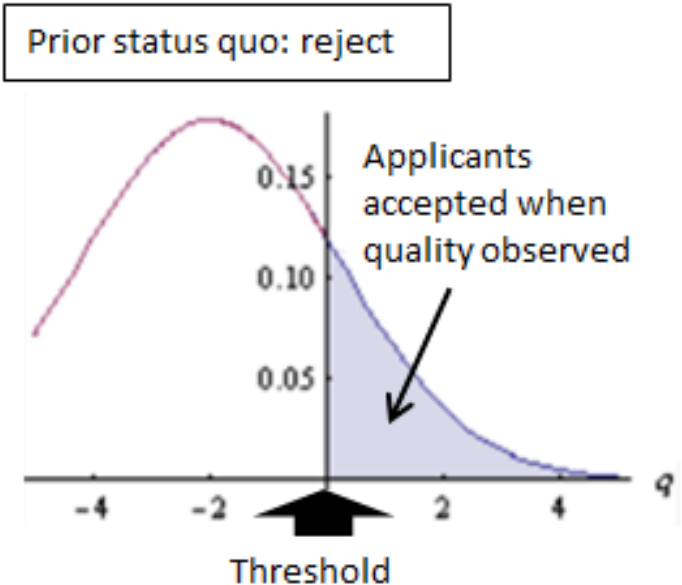

Prior status quo: accept

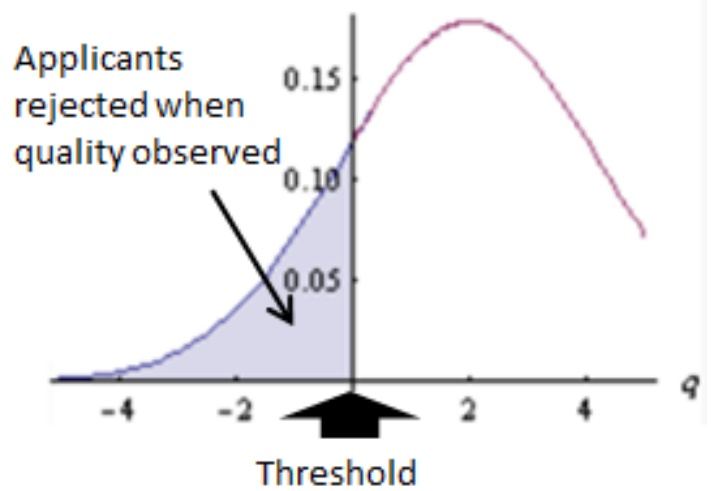


Figure II

Applicant's Personal Website Snapshot (Rental Housing Market)

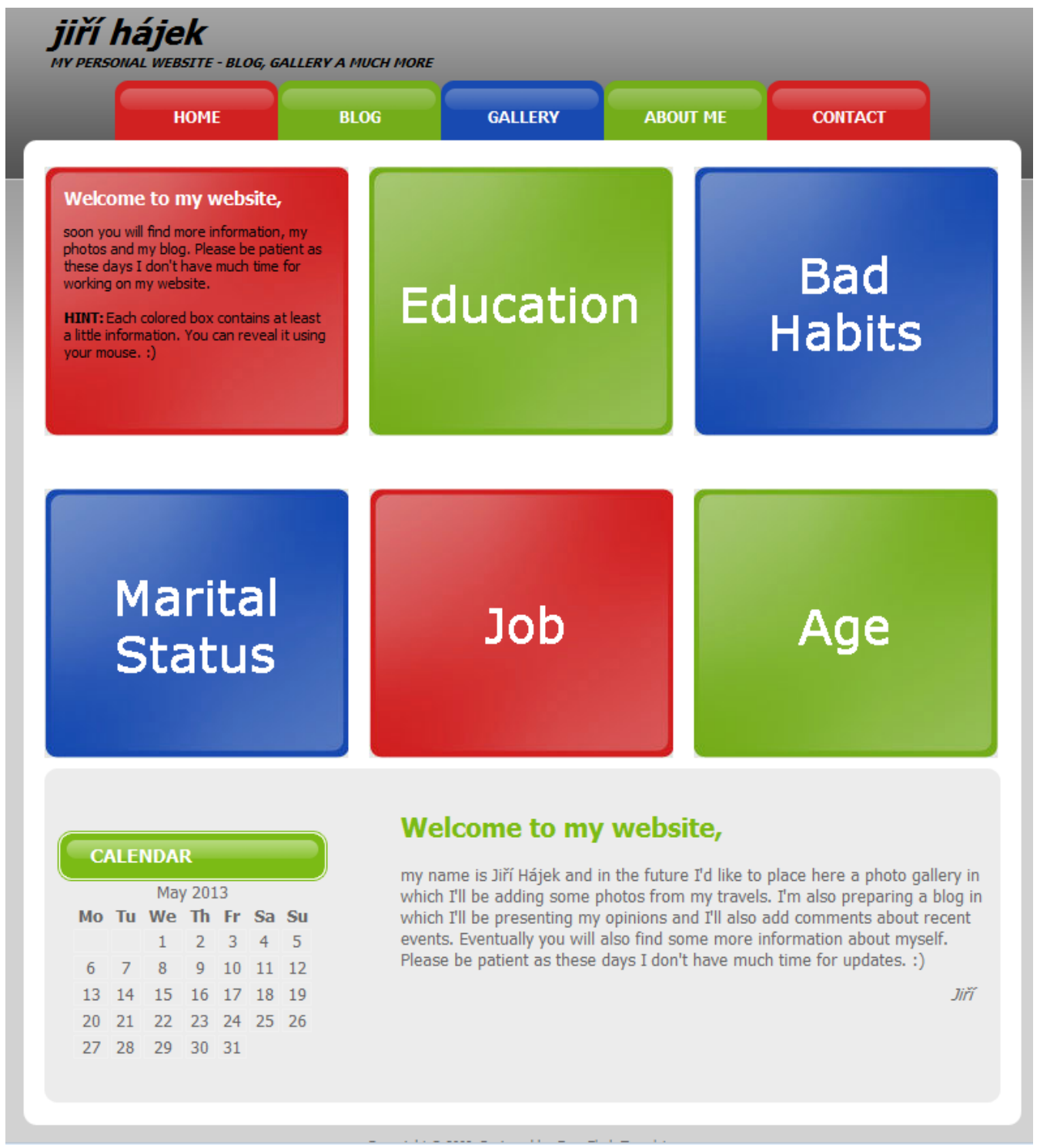


Figure III

Applicant's Online Resume, Labor Market

Left Part: A Snapshot After Opening the Website (a Shorter Form), Right Part: A Snapshot After Expanding Education and Experience Categories

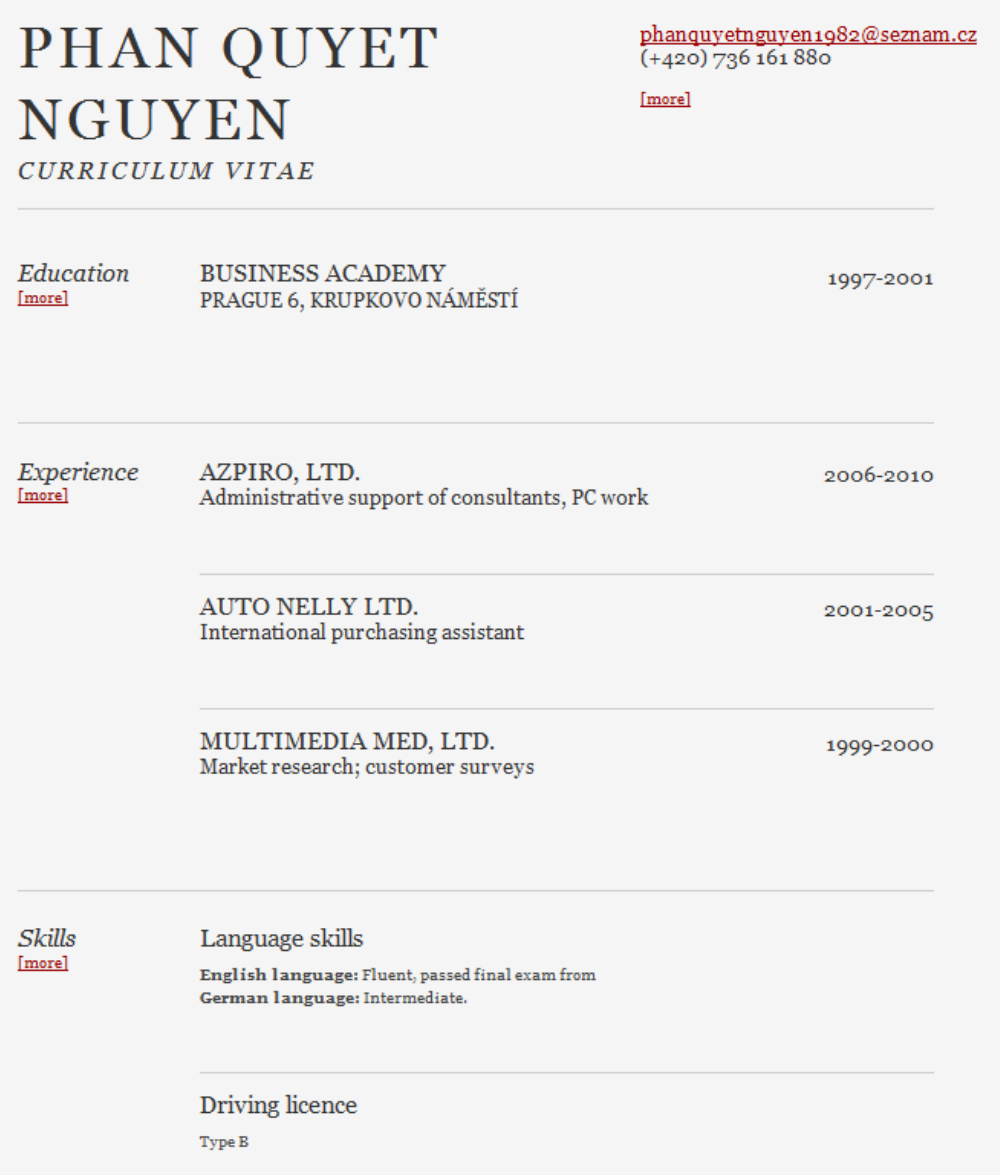
PHAN QUYET $\quad \frac{\text { phanquyetnguyen1982@seznam.cz }}{(+420) 736161880}$ NGUYEN
Mless] Marital status: Single
CURRICULUM VITAE
Date of birth: July 13 th, 1989

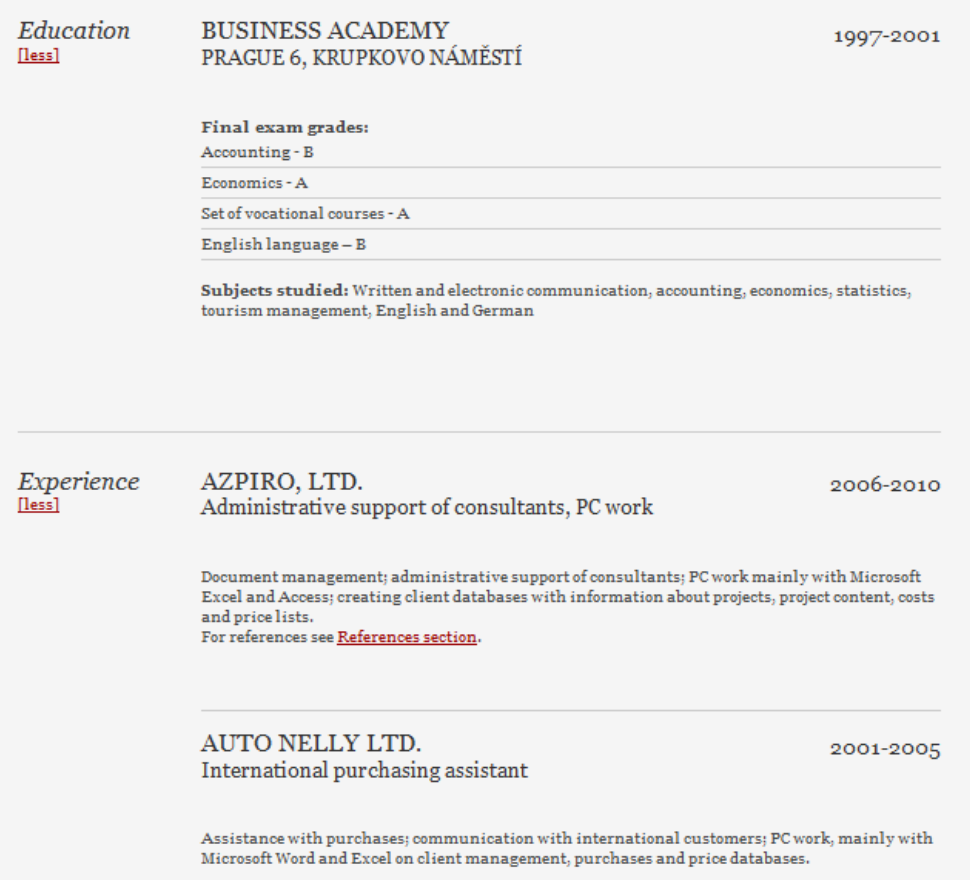




\section{Working Paper Series}

ISSN 1211-3298

Registration No. (Ministry of Culture): E 19443

Individual researchers, as well as the on-line and printed versions of the CERGE-EI Working Papers (including their dissemination) were supported from institutional support RVO 67985998 from Economics Institute of the ASCR, v. v. i.

Specific research support and/or other grants the researchers/publications benefited from are acknowledged at the beginning of the Paper.

(c) Vojtěch Bartoš, Michal Bauer, Julie Chytilová, and Filip Matějka, 2013

All rights reserved. No part of this publication may be reproduced, stored in a retrieval system or transmitted in any form or by any means, electronic, mechanical or photocopying, recording, or otherwise without the prior permission of the publisher.

Published by

Charles University in Prague, Center for Economic Research and Graduate Education (CERGE) and

Economics Institute of the ASCR, v. v. i. (EI)

CERGE-El, Politických vězňů 7, 11121 Prague 1, tel.: +420 224005 153, Czech Republic.

Printed by CERGE-EI, Prague

Subscription: CERGE-EI homepage: http://www.cerge-ei.cz

Phone: + 420224005153

Email: office@cerge-ei.cz

Web: http://www.cerge-ei.cz

Editor: Marek Kapička

The paper is available online at http://www.cerge-ei.cz/publications/working_papers/.

ISBN 978-80-7343-303-1 (Univerzita Karlova. Centrum pro ekonomický výzkum a doktorské studium)

ISBN 978-80-7344-296-5 (Akademie věd České republiky. Národohospodářský ústav) 
CERGE-EI

P.O.BOX 882

Politických vězňů 7

11121 Praha 1

Czech Republic http://www.cerge-ei.cz 